\title{
滑り支承で鉄骨造屋根に接続される RC 片持架構の構面外応答制御設計法 \\ DESIGN PROCEDURE FOR OUT-OF-PLANE RESPONSE CONTROL OF CANTILEVERED RC WALL CONNECTED BY ROLLER SUPPORTS TO METAL SPATIAL ROOF
}

\author{
寺澤友貴*1, 西川幸希*2, 竹内 徹*3, 藤原淳*4, \\ 岸田明子*4, 小西克尚 ${ }^{* 5}$, 山下哲郎*6, 西村 康志郎*7 \\ Yuki TERAZAWA, Koki NISHIKAWA, Toru TAKEUCHI, Jun FUJIWARA, \\ Akiko KISHIDA, Yoshinao KONISHI, Tetsuo YAMASHITA and Koshiro NISHIMURA
}

\begin{abstract}
Design procedure for out-of-plane response control of a cantilevered $\mathrm{RC}$ wall connected by roller supports to metal spatial roof was proposed. This design procedure is carefully formulated based on Japanese structural engineer's practice. The design equation is derived from both equivalent linear approach simulating damping effect and distributed parameter system where a cantilevered RC wall is modeled as single beam or single plate. The accuracy is validated against numerical simulations of damaged school gymnasia and a shake table testing of $1 / 2.5$-scaled model of school gymnasium.
\end{abstract}

\section{Keywords: Cantilevered RC wall, Out-of-plane Response, Roller Support, Friction Damper, School Gymnasium, Spatial Structure $\mathrm{RC}$ 片持架構, 構面外応答, 滑り支承, 摩擦ダンパー, 体育館, 空間構造}

\section{1. 序}

下部 RC 造で支持された鉄骨造屋根の体育館は，鉄骨置屋根体育 館 ${ }^{1) ま た は ~} \mathrm{R}$ 型体育館 ${ }^{2}$ と呼ばれる。鉄骨置屋根体育館では, アリ 一ナ床から片持ちで支持される $\mathrm{RC}$ 架構( $\mathrm{RC}$ 片持架構)が地震時に構 面外に振動(構面外応答)し, 接続する屋根支承部が強制変形を受け, 支承部の敷モルタルのひび割れやアンカーボルトの引張降伏, 支承 部が載る $\mathrm{RC}$ 部材の側方破壊, 支承部に接続する屋根卜ラス部材の 座屈や破断，構造・非構造部材の落下など特有の被害を生じる ${ }^{3)}$ 。

$\mathrm{RC}$ 片持架構の構面外応答が引き起こす諸問題の検定は, 保有水 平耐力計算法など建築基準法が指定する現行の耐震設計法に含まれ ていない。しかし, 体育館は避難施設として災害後も継続使用が求

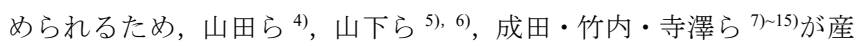
官と連携して精力的に各種検討し, ピン支承で鉄骨造屋根に接続さ れる RC 片持架構の構面外応答検定法は文献 16)に整理された。特 に 2016 年熊本地震以後, $\mathrm{RC}$ 片持架構は構面外応答による柱脚部の 曲げ降伏を許容しない設計方針が一般化しつつある。

一方, 滑り支承(ピンローラー支承)で鉄骨造屋根に接続される RC 片持架構の構面外応答制御設計法は未だ確立していない。筆者らは 同設計法用の手計算の応答評価を既に多数提案 7) 11), 13) しているが， 過度に精度を追求するあまり手順が非常に複雑になっており, 設計 法への実装は難しい。この点について筆者らは有識者にヒアリング を行い, (a)地震荷重は保有水平耐力計算法と同等とする, (b) 実効応
力と変形の算定は実務者の能力に応じて数值解析と手計算の 2 種用 意する，(c)手計算法は出来る限り簡易かつ機械的な手続きとする, (d)力学モデルは実務者が迷わないように質量・剛性の算出を明快と する，(e)ルーズホール端部へのアンカーボルト接触を考慮した強度 型設計も用意する，(f)摩擦ダンパーを導入する制振型設計は特別な 知識を要せず必要耐力が一義的に決まる, 設計法が必要と判明した。 そこで本研究は滑り支承で鉄骨造屋根に接続される $\mathrm{RC}$ 片持架構 の構面外応答制御設計法を改めて提案する。本論文は前述の経緯か ら特に実務者の利便性を優先した構成とする。まず 2 章で結論であ る提案設計法について, 設計に必要な設計クライテリア, 地震荷重, 設計手順，設計式，細則を先に説明し，その後で設計式の導出と検 証を中心に解説する。次の 3 章では設計式の根拠について， RC 片 持架構が構面外応答する時の実効応力と変形の算定法を解説する。 手計算法では, 鉄骨トラスシェルの研究分野で培われてきた連続体 置換法 ${ }^{177}$ に基づき， $\mathrm{RC}$ 片持架構を 1 本の棒または 1 枚の板に置換 した力学モデルと, 連続体振動理論(分布定数系の振動理論)と等価 線形化法を組合せて応答評価する。続く 4,5 章では被災体育館の数 值解析と縮小部分模型の振動台実験結果を用いて 3 章の計算法の妥 当性を検証し，併せて構造細則の根拠を述べる。なお，本研究は防 災科学技術研究所, 東京工業大学, 工学院大学, 日鉄エンジニアリ ングの共同研究で実施した実験結果を引用しており，5章の実験は 別報で詳述予定のため，本論に関係する範囲のみ解説する。

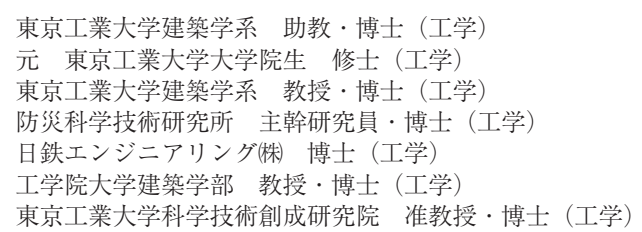

Assist. Prof., Dept. of Arch. and Build. Eng., Tokyo Institute of Technology, Dr.Eng. Former Grad. Student, Tokyo Institute of Technology, M.Eng.

Prof., Dept. of Arch. and Build. Eng., Tokyo Institute of Technology, Dr.Eng. Senior Research Fellow, NIED, Dr.Eng. Nippon Steel Engineering Co., LTD., Dr.Eng. Prof., School of Architecture, Kogakuin Univ., Dr.Eng. Assoc. Prof., Institute of Innovative Research, Tokyo Institute of Technology, Dr.Eng. 
2. 滑り支承で接続される RC 片持架構の構面外応答制御設計法

2.1 総則(適用範囲, 目的と設計クライテリア, 地震荷重, その他) 本章は Fig. 1 の設計フローチャートに沿って本設計法を解説する。 (a) 適用範囲

本設計法は，屋根 $\mathrm{S}$ 造かつ下部 $\mathrm{RC}$ 造で構成される屋内競技場の アリーナ床から片持ちで支持され滑り支承で屋根に接続される $\mathrm{RC}$ 架構(以下， RC 片持架構。スパン約 $46 \mathrm{~m}$ 以下，高さ約 $15 \mathrm{~m}$ 以下，ア リーナ床から 3 層までの高校体育館程度の架構)を適用範囲とする。

(b) 目的と設計クライテリア

本設計法は, RC 片持架構の構面外応答制御を目的とする。滑り支 承のルーズホール端部のアンカーボルト接触を考慮した強度型設計 を除き, 設計クライテリアは, 滑り支承のピーク最大相対変位 $u_{l}$ が ルーズホール長さ $\delta_{l}$ 以下，かつ RC 片持架構の柱脚部曲げモーメン ト $M_{l}$ が降伏曲げモーメント $M_{y}{ }^{19)}$ 未満を満足することとする。

$u_{l} \leqq \delta_{l}$ かつ $M_{l}<M_{y}$

(c) 地震荷重

地震荷重は式(2)の加速度スペクトル $S_{A}$ を用いる。 RC 片持架構は 架構全体から独立して応答すると考え, 架構全体の耐震設計に用い る構造特性係数 $\mathrm{D}_{\mathrm{s}}$ は考慮しない。重要度係数など割増は考慮する。 $S_{A}=Z \cdot R_{t} \cdot C_{0} \cdot G=9800 \cdot Z \cdot R_{t}$ $\left(\mathrm{mm} / \mathrm{s}^{2}\right) \quad(2)$ ここに $Z$ は地域係数, $R_{t}$ は振動特性係数, $C_{0}$ は標準せん断力係数 $\left(C_{0}\right.$ $=1.0), G$ は重力加速度である。殆どの場合 $S_{A}=9.8 \mathrm{~m} / \mathrm{s}^{2}(=1 \mathrm{G})$ となる。

(d) その他

本設計法に規定の無い限り，部材設計は各種規準 ${ }^{18)}$, 19)に従い，滑 り支承の設計は各種合成構造設計指針 ${ }^{20}$ に従い, 架構全体の耐震設 計は建築基準法 ${ }^{21)}$ に従い，その他は必要に応じて条例等 ${ }^{2)}$ に従う。

\section{2 設計手順（以下は 2 層吹き抜けアリーナの設計手順である）}

\section{2.1 Step 1 (架構全体の耐震設計)}

保有水平耐力計算を満たすように架構全体を耐震設計する。

\section{2. 2 Step 2 (RC 片持架構の応力・変形算定の諸元の計算)}

$\mathrm{RC}$ 片持架構はアリーナ床と両端の境界柱が固定支持されている と考え, 以降はそれらの内側の諸元・質量を計算する。アリーナ床 レベルから数えて 1 層目と 2 層目の $\mathrm{RC}$ 柱の断面 2 次モーメント $I_{1}{ }^{(i)}, I_{2}{ }^{(i)}$ と屋根レベルの $\mathrm{RC}$ 梁の断面 2 次モーメント $I_{g}{ }^{(j)}$ は, 該当す る長方形断面の断面二次モーメント $I_{0}$, 鉄筋による増大率 $\phi^{19)}$, 曲げ 降伏時の剛性低下率 $\alpha_{y}{ }^{19}$ をを乗じた割線剛性として式(3)で計算する。 $I_{1}^{(i)}, \quad I_{2}^{(i)}, \quad I_{g}^{(j)}=\alpha_{y} \phi I_{0}$ $\left(\mathrm{mm}^{4}\right) \quad(3)$

ここに $i$ は柱の通り芯番号, $j$ は梁の通し番号である。

$i$ 通り $\mathrm{RC}$ 柱の断面 2 次モーメントは式(4)で 1 つの断面二次モー メント $I_{c}^{(i)}$ に統合する。3 層吹き抜けの計算式は付録を参照する。

$I_{c}^{(i)}=\frac{I_{1}^{(i)} I_{2}^{(i)}\left(h^{(i)}\right)^{3}}{\left(I_{1}^{(i)}-I_{2}^{(i)}\right)\left(h_{2}^{(i)}\right)^{3}+I_{2}^{(i)}\left(h^{(i)}\right)^{3}}$ $\left(\mathrm{mm}^{4}\right)$

RC 片持架構を代表する諸元として，柱の等価断面二次モーメン 卜 $I_{c e q}$, 梁の等価断面二次モーメント $I_{g e q}$, 柱の代表高さ $h_{c}$, 梁の代 表高さ $h_{g}$, 等価平板の曲げ剛性 $D_{x}$ と $D_{y}$ は式(5) 式(10)で計算し, Fig.1 中グラフより応答に対する梁の影響係数 $q$ と $q_{p}$ を読み取る。

$I_{c e q}=$ Average of $\left\{I_{c}^{(i)}\right\}$

$I_{\text {geq }}=$ Average of $\left\{I_{g}{ }^{(j)}\right\}$

$h_{c}=$ Maximum of $\left\{h^{(i)}\right\}$

$h_{g}=$ Average of $\left\{h_{2}{ }^{(i)}\right\}$
$D_{x}=E I_{c e q}\left(n_{c}+1\right) / L$

(Nmm)

$D_{y}=E I_{g e q} / h_{g}$

(Nmm) (10)

ここに $h_{1}{ }^{(i)}$ は $i$ 通り 1 層の階高, $h_{2}{ }^{(i)}$ は $i$ 通り 2 層の階高, $h^{(i)}=h_{1}{ }^{(i)}+h_{2}{ }^{(i)}$, $n_{c}$ は境界柱を除いた柱の通り総数, $E$ はコンクリートのヤング率 ${ }^{19)}$, $L$ は RC 片持架構全体の幅である。

\subsubsection{Step 3（RC 片持架構の構面外応答検定）}

(a)手計算を用いる場合

$u_{l}$ と $M_{l}$ は式(11) 式(14)で評価し，式(1)で構面外応答検定する。

$$
\begin{aligned}
& u_{l}=u_{l 0}=1.2 \times\left\{\begin{array}{lll}
2.066 S_{A} / \omega_{w}^{2} & (q>0.409) \\
1.566 S_{A} / \omega_{c}^{2} & (q \leq 0.409)
\end{array}\right. \\
& M_{l}=M_{l 0}=r \times\left\{\begin{array}{lll}
7.265 D_{x} l_{c} S_{A} /\left(h_{c}^{2} \omega_{w}^{2}\right) & (q>0.409) \\
5.506 E I_{c}{ }^{\text {center }} S_{A} /\left(h_{c}^{2} \omega_{c}^{2}\right) & (q \leq 0.409)
\end{array}\right. \\
& \omega_{w}=312 q \sqrt{D_{x} L /\left(m_{w} h_{c}^{3}\right)}
\end{aligned}
$$

ここに $m_{w}$ はアリーナ床梁と境界柱より内側の全負担質量, $m_{c}$ は柱 の負担幅 $l_{c}$ (両側半スパン和)の全負担質量, $\omega_{w}$ と $\omega_{c}$ は固有円振動数, $I_{c}^{\text {center }}$ は中央 $(y=0.5 L)$ に最も近い $I_{c}^{(i)}$ であり, $r$ はグラフから読み取る。 (b)骨組モデルの応力解析を用いる場合

Fig.1 に示すように，RC 片持架構だけの骨組モデルを構築し，節 点質量 $\times S_{A}$ の節点力を構面外方向に与えて応力解析する。解析結果 より $u_{l}$ と $M_{l}$ を抽出して, 式(1)で構面外応答を検定する。

\section{2.4 Step 4 (Step3 で式 (1) を満足しない場合の対応)}

Design option 1 : 式(1)を満足するまで部材と支承を再設計する。

Design option 2 : 支承部反力の発生を認める強度型設計

$Q_{s}$ に対して $\mathrm{RC}$ 部材, 滑り支承, 屋根部材を許容応力度設計する。

(a)手計算を用いる場合

$$
Q_{s}= \begin{cases}10.00 D_{x} l_{c} S_{A} /\left(h_{c}^{3} \omega_{w}^{2}\right) & (q>0.409) \\ 7.578 E I_{c}^{\text {center }} S_{A} /\left(h_{c}^{3} \omega_{c}^{2}\right) & (q \leq 0.409)\end{cases}
$$

(b)骨組モデルの静的応力解析を用いる場合

2.2.3 項 Step 3 (b)の $\mathrm{RC}$ 柱が負担する最大ベースシアを $Q_{s}$ とする。 Design option 3 : 摩擦ダンパーを用いた制振型設計

滑り支承 1 台辺りの必要ダンパー耐力 $Q_{d}$ は必要応答低減率 $R_{d}$, 代 表台数 $n$, 支承部数 $n_{d}$ と代表剛性 $K_{e q}$ より式(16) 式(19)で計算する。

$$
\begin{aligned}
Q_{d} & =n K_{e q} u_{l 0}\left(-0.279 R_{d}{ }^{3}+0.653 R_{d}^{2}-0.725 R_{d}+0.351\right) / n_{d} \\
R_{d} & =\delta_{l} / u_{l 0} \\
n & = \begin{cases}1 & (q>0.409) \\
n_{c} & (q \leq 0.409)\end{cases} \\
K_{e q} & = \begin{cases}4.23 \times 10^{-4} m_{w} \omega_{w}^{2} & (q>0.409) \\
6.13 \times 10^{-4} m_{c} \omega_{c}^{2} & (q \leq 0.409)\end{cases}
\end{aligned}
$$

$(\mathrm{N} / \mathrm{mm}) \quad(19)$

(a)手計算を用いる場合

$$
\begin{aligned}
& u_{l}=R_{d} u_{l 0} \\
& M_{l}=\max \left\{R_{d} M_{l 0}, M_{l p}\right\} \\
& M_{l p}= \begin{cases}4.798 M_{l 0}\left(q^{2} / q_{p}^{2}\right) & (q>0.409) \\
0.248 M_{l 0} & (q \leq 0.409)\end{cases}
\end{aligned}
$$

(Nmm)

(b)骨組モデルの静的応力解析を用いる場合

屋根レベルの節点外力から $Q_{d}{ }^{\prime}(i)$ を差し引き $u_{l}$ と $M_{l}$ を再評価する。

$$
Q_{d}^{\prime}{ }^{(i)}=n_{d} Q_{d}{ }^{(i)} m_{2}^{(i)} / \sum_{i=1}^{n_{c}} m_{2}^{(i)}
$$

\section{2.5 Step 5 (Step 4 で制振型設計を選択した場合)}

式(1)を満足する場合は $Q_{d}$ に対して支承と屋根部材を許容応力度 設計する。満足しない場合はStep 1 亿戻り支承と部材を再設計する。 


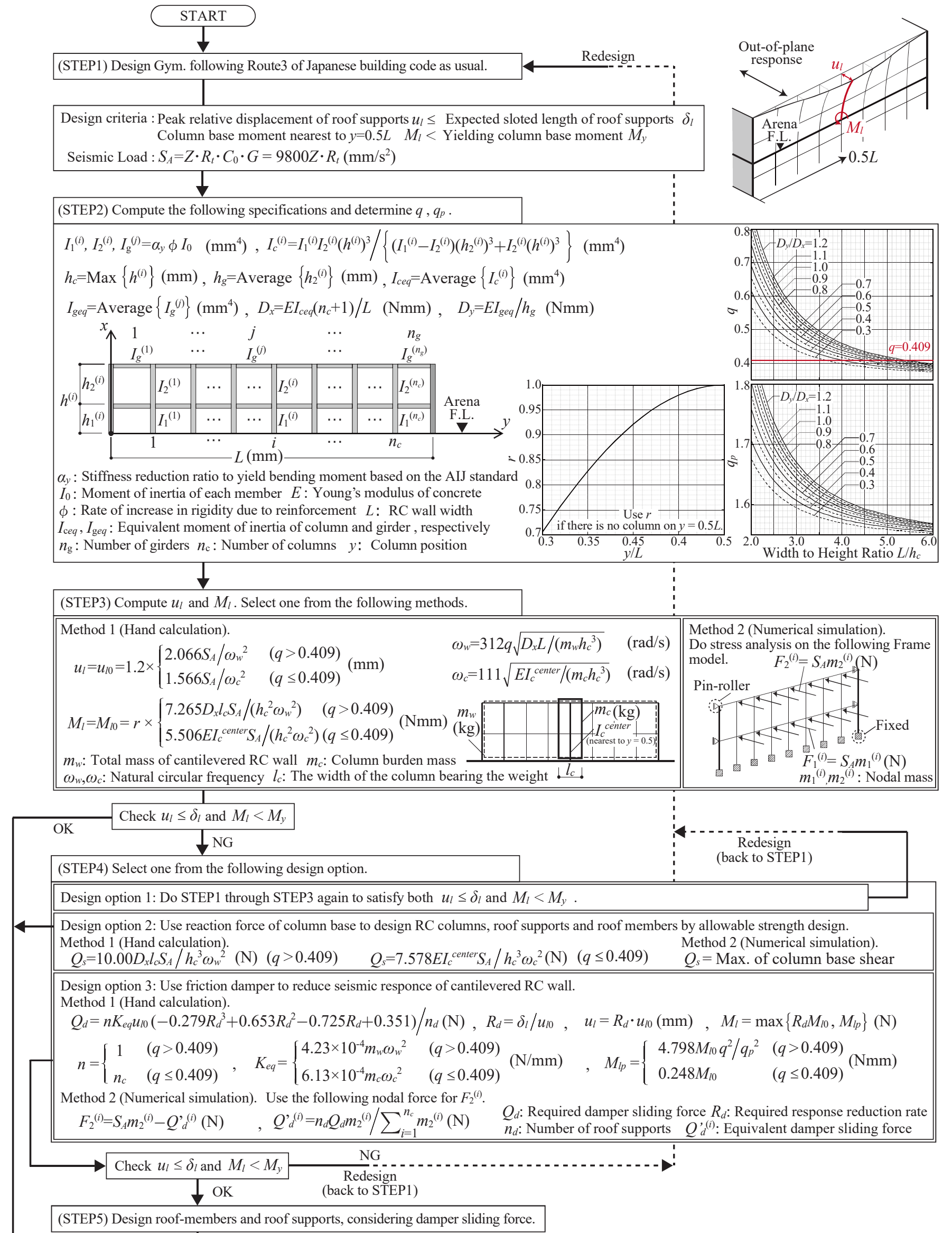

Fig. 1 Flow chart of design procedure for out-of-plane response control of cantilevered RC wall connected by roller supports to metal spatial roof 


\section{RC 片持架構の構面外応答の算定手法}

本設計法は RC 片持架構の構面外応答を弾性範囲に留めることを 前提条件としており, その範囲内の応答は曲げ降伏点の割線剛性で モデル化した弾性体の振動理論と数值的な応力解析より算出できる。

\section{1 手計算を用いた算定手法}

手計算法を用いた算定手法では，連続体置換法に基づき $\mathrm{RC}$ 片持 架構を 1 本の棒または 1 枚の板の力学モデルに置換し, 1 次モード の連続体振動理論と等価線形化法を組合せて応答評価する。

\section{1.1 連続体置換法に基づく置換弾性体の力学モデルの構築}

Fig. 2 に連続体置換の概要を示す。連続体置換法では, 元となる骨 組架構の補歪エネルギー $W_{d}$ と置換弾性体の補歪エネルギー $W_{e}$ を等 置して置換弾性体の有効剛性を算出寸る ${ }^{17) 。}$

Fig. 2(a)に示すように, RC 片持架構を $i$ 通りの柱から 1 本の棒に 置換する場合の $W_{d}$ と $W_{e}$ は式(24), 置換弾性棒の断面 2 次モーメン ト $I_{c}^{(i)}$ は式(25), 断面積 $A_{c}^{(i)}$ は式(26) となる。また, 置換弾性棒の密度 $\rho_{c}^{(i)}$ は代表高さ $h_{c}\left(\right.$ 式(7)) と負担幅 $l_{c}^{(i)}($ 柱に接続する両側スパンの半 分)で囲われる全負担質量 $m_{c}^{(i)}$ より式(27)で計算する。

$$
\begin{aligned}
W_{d} & =\frac{1}{2} \int_{0}^{h_{2}^{(i)}} \frac{(P x)^{2}}{E I_{2}^{(i)}} d x+\frac{1}{2} \int_{h_{2}^{(i)}}^{h^{(i)}} \frac{(P x)^{2}}{E I_{1}^{(i)}} d x, \quad W_{e}=\frac{1}{2} \int_{0}^{h^{(i)}} \frac{(P x)^{2}}{E I_{c}^{(i)}} d x \\
I_{c}^{(i)} & =\frac{I_{1}^{(i)} I_{2}^{(i)}\left(h^{(i)}\right)^{3}}{\left(I_{1}^{(i)}-I_{2}^{(i)}\right)\left(h_{2}^{(i)}\right)^{3}+I_{2}^{(i)}\left(h^{(i)}\right)^{3}} \\
A_{c}^{(i)} & =\frac{A_{1}^{(i)} A_{2}^{(i)} h^{(i)}}{A_{1}^{(i)} h_{2}^{(i)}+A_{2}^{(i)} h_{1}^{(i)}} \\
\rho_{c}^{(i)} & =m_{c}^{(i) /}\left(h_{c} A_{c}^{(i)}\right)
\end{aligned}
$$

Fig. 2(b)に示すように, RC 片持架構を 1 枚の板に置換する場合で は, 式(5) 式(8)で計算される $\mathrm{RC}$ 片持架構の諸元を平均化した等価 断面 2 次モーメント $I_{c e q}, I_{g e q}$ と代表高さ $h_{g}$, 代表幅 $L /\left(1+n_{c}\right)$ で構成 される直交格子を元として, 置換弾性板の曲げ岡性 $D_{x}$ と $D_{y}$, 板厚

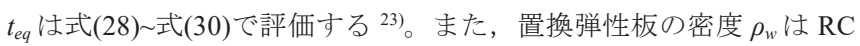
片持架構の全質量 $m_{w}$, 代表高さ $h_{c}$, 全体幅 $L$ より式(31)で計算する。

$$
\begin{aligned}
D_{x} & =E I_{\text {ceq }}\left(n_{c}+1\right) / L \\
D_{y} & =E I_{g e q} / h_{g} \\
t_{e q} & =\sqrt{12 D_{x}\left(1-v_{x} v_{y}\right)} \quad ※ v_{x} v_{y}=0.04 \\
\rho_{w} & =m_{w} /\left(h_{c} L t_{e q}\right)
\end{aligned}
$$

\subsection{2 棒の連続体振動理論と応答スペクトル法に基づく応答評価}

固定端を原点, 材軸方向を $x$ 軸とする弾性棒の 1 次モード応答は 時刻 $T$ の 1 自由度系応答 $Z(T)$ (式(32)) と座標 $x$, 未定係数 $C_{i}$ の形状 関数 $w(x)($ 式(33))の積で表す。常微分自由振動方程式は式(34)となる。

$$
\zeta(x, T)=w(x) Z(T)
$$

$w(x)=C_{1} \cos a x+C_{2} \sin a x+C_{3} \cosh a x+C_{4} \cosh a x$

$$
\ddot{Z}(T)+\omega^{2} Z(T)=0, \frac{d w(x)}{d x^{4}}-a^{4} w(x)=0, a^{4}=\frac{\omega^{2} \rho_{c} A_{c}^{(i)}}{E I_{c}^{(i)}}
$$

支承が滑る時(固定端-自由端)の形状関数 $w_{c}(x)$, 固有円振動数 $\omega_{c}$, 刺激係数 $\Gamma_{c}$, モ一ド質量 $m_{c e q}$, モ一ド剛性 $K_{c e q}$, 支承部相対変位 $u_{l 0 c}$, 柱脚部曲げモーメント $M_{l 0 c}$, 柱脚部ベースシア $Q_{s c}$ は無次元化振動 数 $\lambda_{c}(=1.875)$ より式(35) 式(42)で計算できる。

$w_{c}(x)=+\left(\cos \lambda_{c}+\cosh \lambda_{c}\right)\left(\sin \lambda_{c} x / h_{c}-\sinh \lambda_{c} x / h_{c}\right)$ $-\left(\sin \lambda_{c}+\sinh \lambda_{c}\right)\left(\cos \lambda_{c} x / h_{c}-\cosh \lambda_{c} x / h_{c}\right)$

$$
\omega_{c}=\left(\frac{\lambda_{c}}{h_{c}}\right)^{2} \sqrt{\frac{E I_{c}^{(i)}}{\rho_{c}^{(i)} A_{c}^{(i)}}}=\left(\frac{1.875}{h_{c}}\right)^{2} \sqrt{\frac{E I_{c}^{(i)}}{\rho_{c}^{(i)} A_{c}^{(i)}}}=3.516 \sqrt{\frac{E I_{c}^{(i)}}{m_{c} h_{c}^{3}}}
$$

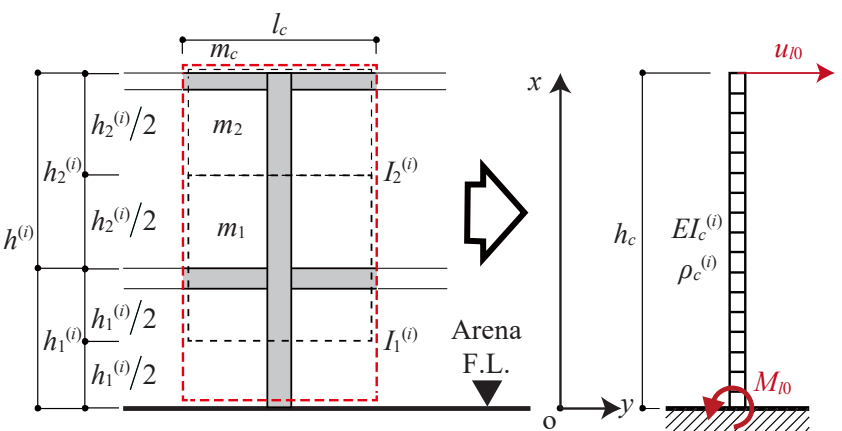

(a) Translation from frame model to equivalent beam model

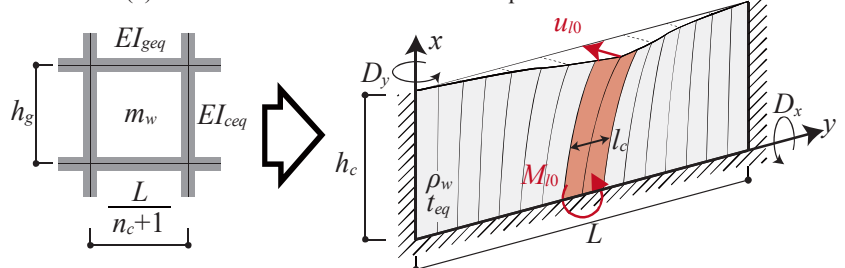

(b) Translation from frame model to equivalent plate model

Fig. 2 Schematic of translation by slab analogies

$$
\begin{aligned}
& \Gamma_{c}=\int_{0}^{h_{c}} w_{c}(x) d x / \int_{0}^{h_{c}}\left(w_{c}(x)\right)^{2} d x=0.189 \quad \text { (定数) } \\
& m_{c e q}=\Gamma_{c}^{2} \rho_{c}^{(i)} A_{c}^{(i)} \int_{0}^{h_{c}}\left(w_{c}(x)\right)^{2} d x=0.613 m_{c} \\
& K_{c e q}=m_{c e q} \omega_{c}^{2} \\
& u_{l 0 c}=\Gamma_{c}\left(S_{A} / \omega_{c}^{2}\right) w_{c}\left(h_{c}\right)=1.566\left(S_{A} / \omega_{c}^{2}\right) \\
& M_{l 0 c}=r \times\left.\Gamma_{c} E I_{c}^{(i)} \frac{S_{A}}{\omega_{c}^{2}} \frac{d^{2} w_{c}(x)}{d x^{2}}\right|_{x=0} \simeq r \times 5.506 \frac{E I_{c}^{(i)}}{h_{c}^{2}} \frac{S_{A}}{\omega_{c}^{2}} \\
& Q_{s c}=\left.\Gamma_{c} E I_{c}^{(i)} \frac{S_{A}}{\omega_{c}^{2}} \frac{d^{3} w_{c}(x)}{d x^{3}}\right|_{x=0} \simeq 7.578 \frac{E I_{c}^{(i)}}{h_{c}^{3}} \frac{S_{A}}{\omega_{c}^{2}}
\end{aligned}
$$

摩擦ダンパーで支承が移動を拘束される場合(固定端-ピン端)の 形状関数 $w_{c p}(x)$, 固有円振動数 $\omega_{c p}$, 刺激係数 $\Gamma_{c p}$, 柱脚部曲げモーメ ント $M_{l p c}$ は無次元化振動数 $\lambda_{c p}(=3.927)$ より式(43) 式(46)で表される。

$w_{c p}(x)=-\left(\cos \lambda_{c p}+\cosh \lambda_{c p}\right)\left(\cos \lambda_{c p} x / h_{c}-\cosh \lambda_{c p} x / h_{c}\right)$ $+\left(\sin \lambda_{c p}+\sinh \lambda_{c p}\right)\left(\sin \lambda_{c p} x / h_{c}-\sinh \lambda_{c p} x / h_{c}\right)$

$\omega_{c p}=\left(\frac{\lambda_{c p}}{h_{c}}\right)^{2} \sqrt{\frac{E I_{c}^{(i)}}{\rho_{c}^{(i)} A_{c}^{(i)}}}=\left(\frac{3.927}{h_{c}}\right)^{2} \sqrt{\frac{E I_{c}^{(i)}}{\rho_{c}^{(i)} A_{c}^{(i)}}}$

$\Gamma_{c p}=\int_{0}^{h_{c}} w_{c p}(x) d x / \int_{0}^{h_{c}}\left(w_{c p}(x)\right)^{2} d x=0.0347 \quad$ (定数)

$M_{l p c}=r \times\left.\Gamma_{c p} E I_{c}^{(i)} \frac{S_{A}}{\omega_{c p}^{2}} \frac{d^{2} w_{c p}(x)}{d x^{2}}\right|_{x=0} \simeq r \times 26.42 \frac{E I_{c}^{(i)}}{h_{c}^{2}} \frac{S_{A}}{\omega_{c p}^{2}}=0.248 M_{l 0 c}$

摩擦ダンパー導入後の支承部相対変位 $u_{l d c}$ は応答低減率 $R_{d}$ より式 (47)で，柱脚部曲げモーメント $M_{l d c}$ は支承が滑らない状態を下限と して式(48)で評価する。アンカーボルトがルーズホール端部に接触 する場合では, $\mathrm{RC}$ 部材, 支承, 屋根部材に $Q_{s c}$ が伝達すると考える。

$$
u_{l d c}=R_{d} u_{l 0 c}
$$

$M_{l d c}=$ Maximum of $\left\{R_{d} M_{l 0 c}, M_{l p c}\right\}$

なお, 簡単のため式(34)はせん断変形の影響を考慮していない。一 般にアスペクト比 3 で $u_{10 c}$ は約 $30 \%$ 過小評価となるが，その場合の 柱せいは $3 \mathrm{~m}$ 超のバットレス相当であり構面外応答は十分収まる。

\subsection{3 板の連続体振動理論と応答スペクトル法に基づく応答評価}

Fig. 2(b)に示寸座標系を仮定したとき, 直交異方性弾性板の自由 振動方程式は式(49)で表される。モード形状関数 $w(x, y)$ は式(33) と同 様の各方向形状関数 $w(x)$ と $w(y)$ の積として式(50)で表す。

$$
D_{x} \frac{\partial^{4} \zeta}{\partial x^{4}}+2\left(D_{1}+2 D_{x y}\right) \frac{\partial^{4} \zeta}{\partial x^{2} \partial y^{2}}+D_{y} \frac{\partial^{4} \zeta}{\partial y^{4}}+\rho_{w} t_{e q} \frac{\partial^{2} \zeta}{\partial T^{2}}=0
$$

$w(x, y)=w(x) w(y)$ 
ここに $D_{x}$ は $y$ 軸回りの面外曲げ剛性, $D_{y}$ は $x$ 軸回りの面外曲げ剛 性, $D_{1}$ は $v_{y} D_{x}=\left(\nu_{x} D_{y}\right), D_{x y}$ は $x y$ 面の面内せん断剛性である。

Rayleigh-Ritz 法より $w(x, y)$ が 1 3 次モードの形状関数の 1 次結合 式(51)で表されるとき, その未定係数ベクトル\{c\}は, 連続体内のポ テンシャルエネルギーと運動エネルギーを等置した時の固有円振動 数 $\omega$ に関する停留条件式(52)より求まる。

$$
w(x, y)=c_{1} w_{1}(x, y)+c_{2} w_{2}(x, y)+c_{3} w_{3}(x, y)
$$

$$
\omega^{2}=\frac{D_{x}}{\rho_{w} t_{e q}} \frac{\iint\left[\frac{\partial^{4} w}{\partial x^{4}}+2 \frac{\left(D_{1}+2 D_{x y}\right)}{D_{x}} \frac{\partial^{4} w}{\partial x^{2} \partial y^{2}}+\frac{D_{y}}{D_{x}} \frac{\partial^{4} w}{\partial y^{4}}\right] d x d y}{\iint(w(x, y))^{2} d x d y}, \frac{\partial \omega^{2}}{\partial\{c\}}=\{0\}
$$

実際に各境界条件を満足する式(51)を式(52)に代入してベクトル 微分を実行すると, 未定係数 $c_{1} \sim c_{3}$ に関する同次連立方程式が得られ る。これを解くと $\omega$ に加えて, 辺長比 $L / h_{c}$ に関する係数 $b$ と $b_{p}$, 異 方性 $D_{y} / D_{x}$ (柱梁の剛比とも言える)に関する係数 $c$ と $c_{p}$ が得られる が, 非常に複雑な行列式の解となるため本論は Fig. 3 として与える。

支承が滑る時(固定端-自由端)の形状関数 $w_{w}(x)$ と $w_{w}(y)$, 固有円振 動数 $\omega_{w}$, 刺激係数 $\Gamma_{w}$, モード質量 $m_{w e q}$, モード剛性 $K_{w e q}$, 支承部相 対変位 $u_{10 w}$, 柱脚部曲げモーメント $M_{l 0 w}$, 柱脚部ベースシア $Q_{s w}$ は無 次元化振動数 $\lambda_{w}(=4.730)$ より式(53) 式(61)で計算できる。

$$
\begin{aligned}
& w_{w}(x)=+\left(\cos \lambda_{c}+\cosh \lambda_{c}\right)\left(\sin \lambda_{c} x / h_{c}-\sinh \lambda_{c} x / h_{c}\right) \\
& -\left(\sin \lambda_{c}+\sinh \lambda_{c}\right)\left(\cos \lambda_{c} x / h_{c}-\cosh \lambda_{c} x / h_{c}\right) \\
& w_{w}(y)=+\left(\cos \lambda_{w}-\cosh \lambda_{w}\right)\left(\cos \lambda_{w} y / L-\cosh \lambda_{w} y / L\right) \\
& \left(\sin \lambda_{w}+\sinh \lambda_{w}\right)\left(\sin \lambda_{w} y / L-\sinh \lambda_{w} y / L\right) \\
& \omega_{w}=b \cdot c \cdot \frac{\pi^{2}}{h_{c}^{2}} \sqrt{\frac{D_{x}}{\rho_{w} t_{e q}}}=\pi^{2} q \sqrt{\frac{D_{x} L}{m_{w} h_{c}^{3}}} \quad(\because q=b c) \\
& \Gamma_{w}=\int_{0}^{L} \int_{0}^{h_{c}} w(x, y) d x d y / \int_{0}^{L} \int_{0}^{h_{c}}(w(x, y))^{2} d x d y=0.00278 \quad \text { (定数) } \\
& m_{\text {weq }}=\Gamma_{w}^{2} \rho_{w} t_{e q} \int_{0}^{L} \int_{0}^{h_{c}}(w(x, y))^{2} d x d y=0.423 m_{w} \\
& K_{\text {weq }}=m_{\text {weq }} \omega_{w}{ }^{2} \\
& u_{l 0 w}=\Gamma_{w}\left(S_{A} / \omega_{w}{ }^{2}\right) w\left(h_{c}, 0.5 L\right)=2.066\left(S_{A} / \omega_{w}{ }^{2}\right) \\
& M_{l 0 w}=r \times\left.\Gamma_{w} D_{x} l_{c} \frac{S_{A}}{\omega_{w}^{2}} \frac{\partial^{2} w(x, y)}{\partial x^{2}}\right|_{x, y=0,0.5 L} \simeq r \times 7.265 \frac{D_{x} l_{c}}{h_{c}^{2}} \frac{S_{A}}{\omega_{w}^{2}} \\
& Q_{s w}=\left.\Gamma_{w} D_{x} l_{c} \frac{S_{A}}{\omega_{w}^{2}} \frac{\partial^{3} w(x, y)}{\partial x^{3}}\right|_{x, y=0,0.5 L} \simeq 10.0 \frac{D_{x} l_{c}}{h_{c}^{3}} \frac{S_{A}}{\omega_{w}^{2}}
\end{aligned}
$$

摩擦ダンパーで支承が移動を拘束される場合(固定端-ピン端)の 形状関数 $w_{w p}(x)$, 固有円振動数 $\omega_{w p}$, 刺激係数 $\Gamma_{w p}$, 柱脚部曲げモー メント $M_{l p w}$ は式(54)と式(62) 式(65)で表される。

$w_{w p}(x)=-\left(\cos \lambda_{c p}+\cosh \lambda_{c p}\right)\left(\cos \lambda_{c p} x / h_{c}-\cosh \lambda_{c p} x / h_{c}\right)$

$+\left(\sin \lambda_{c p}+\sinh \lambda_{c p}\right)\left(\sin \lambda_{c p} x / h_{c}-\sinh \lambda_{c p} x / h_{c}\right)$

$\omega_{w p}=b_{p} \cdot c_{p} \cdot \frac{\pi^{2}}{h_{c}^{2}} \sqrt{\frac{D_{x}}{\rho_{w} t_{e q}}}$

$\Gamma_{w p}=\int_{0}^{L} \int_{0}^{h_{c}} w(x, y) d y d x / \int_{0}^{L} \int_{0}^{h_{c}}(w(x, y))^{2} d y d x=0.000509 \quad$ (定数)

$M_{l p w}=r \times\left.\Gamma_{w p} D_{x} l_{c} \frac{S_{A}}{\omega_{w p}^{2}} \frac{\partial^{2} w(x, y)}{\partial x^{2}}\right|_{x, y=0,0.5 L} \simeq 4.798\left(\frac{q}{q_{p}}\right)^{2} M_{l 0 w}$

摩擦ダンパー導入後の支承部相対変位 $u_{l d w}$ は応答低減率 $R_{d}$ より式 (66)で, 柱脚部曲げモーメント $M_{l d w}$ は支承が滑らない状態を下限と して式(67)で評価する。アンカーボルトがルーズホール端部に接触 する場合は, $\mathrm{RC}$ 部材, 支承, 屋根部材に $Q_{s c w}$ が伝達すると考える。

$$
\begin{aligned}
& u_{l d w}=R_{d} u_{l 0 w} \\
& M_{l d w}=\text { Maximum of }\left\{R_{d} M_{l 0 w}, M_{l p w}\right\}
\end{aligned}
$$

\subsection{4 棒と板の応答評価の場合分け}

$m_{c}=m_{w} l_{c} / L$ から棒と板の支承部相対変位の比 $u_{l 0 c} / u_{10 w}$ は式(68)で表 される。この比が 1.0 となる条件は $b c=q=0.409$ であり, $q \leqq 0.409$
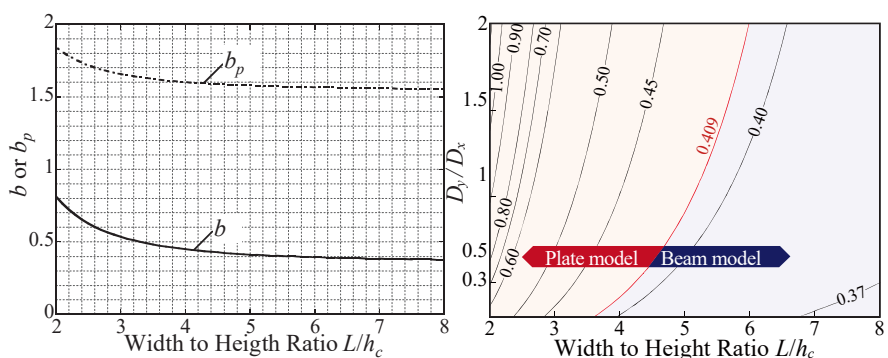

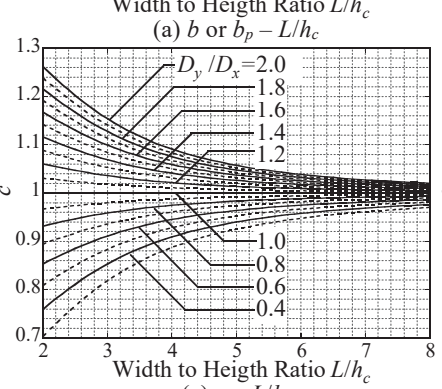

(c) $c-L / h_{c}$

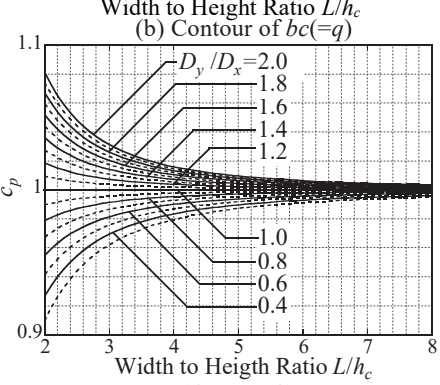

(d) $c_{p}-L / h_{c}$

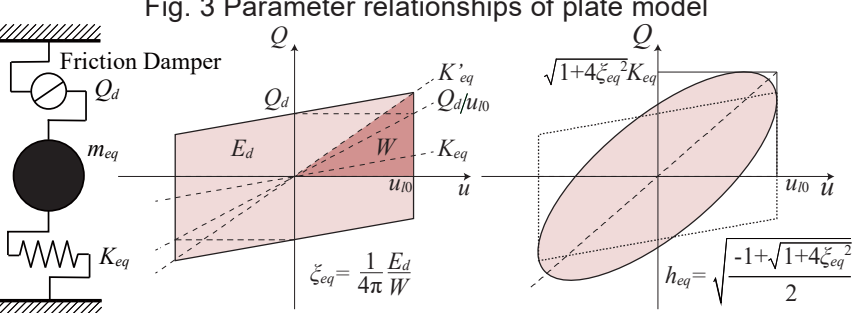

(a) Equivalent SDOF (b) Elasto-plastic hysteresis (c) Complex stiffness hysteresis Fig. 4 Evaluating additional damping ratio by friction damper

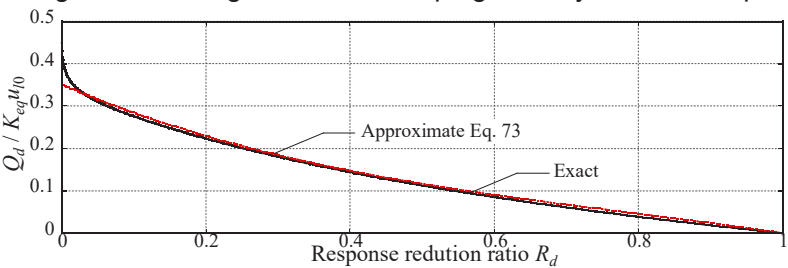

Fig. $5 Q_{d} /\left(K_{e q} U_{10}\right)-R_{d}$ relationship

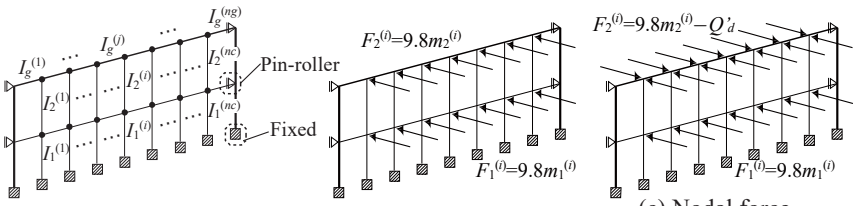

(a) Model

(b) Nodal force

(c) Nodal force

including friction dampers

Fig. 6 Schematic of method 2 by numerical frame model

では板の応答が過大評価, $q>0.409$ では棒の応答が過大評価となる ため，本設計法は $q=0.409$ を手法の場合分けの闇值とする。

$u_{l 0 c} / u_{l 0 w}=5.974 b^{2} c^{2} \rightarrow q=b c=0.409 \quad\left(u_{l 0 c} / u_{l 0 w}=1.0\right)$

\subsection{5 等価線形化法に基づく摩擦ダンパーの応答低減効果の反映}

Fig. 4 に等価線形化法の概要を示す。耐力 $Q_{d}$ の摩擦ダンパーを付 加した等価 1 自由度系の等価剛性 $K_{\text {eq }}$, 要素減衰比 $\xi_{e q}$ は式(69) と式 (70)で表し, 系の等価減衰比 $h_{e q}$ は複素剛性法より式(71)で評価する。

$$
\begin{aligned}
& K_{e q}{ }^{\prime}=K_{e q}+Q_{d} / u_{l 0} \\
& \xi_{e q}=\frac{1}{4 \pi} \frac{E_{d}}{0.5 K_{e q}^{\prime} u_{l 0}^{2}}=\frac{2}{\pi\left\{1+Q_{d} /\left(K_{e q} u_{l 0}\right)\right\}} \frac{Q_{d}}{K_{e q} u_{l 0}} \\
& h_{e q}=\sqrt{\frac{-1+\sqrt{1+4 \xi_{e q}^{2}}}{2}}
\end{aligned}
$$

摩擦ダンパーの付加を考慮した等価周期 $T_{e q}$ と応答低減効果係数 $D_{h}$ より変位応答低減率 $R_{d}$ は式(72)で表される ${ }^{24)}$ 。 


$$
R_{d}=D_{h}\left(\frac{T_{e q}}{T_{0}}\right)^{2}=\sqrt{\frac{1+25 h_{0}}{1+25\left(h_{0}+h_{e q}\right)}}\left(1+\frac{Q_{d}}{K_{e q} u_{l 0}}\right)^{-1}
$$

様々な耐力比 $Q_{d} /\left(K_{e q} u_{10}\right)$ に対して式(69) 式(72)を 20 回収斂計算し て求めた $R_{d}$ は Fig. 5 の通りであり, 多項式近似式は式(73)となる。

$$
Q_{d} /\left(K_{e q} u_{l 0}\right)=-0.279 R_{d}{ }^{3}+0.653 R_{d}{ }^{2}-0.725 R_{d}+0.351
$$

\subsection{6 片持梁のたわみ変形公式を用いた静的な評価 (比較用)}

2 点集中荷重を受ける片持梁の静的な評価は式(74) と式(75)とする。 $u_{l 0}=\left\{S_{A} /\left(6 E I_{c}^{(i)}\right)\right\}\left\{2 m_{2}{ }^{(i)} h_{c}{ }^{3}+m_{1}{ }^{(i)} h_{1}{ }^{(i) 2}\left(3 h_{c^{-}} h_{1}{ }^{(i)}\right)\right\}$

$M_{l 0}=S_{A}\left\{m_{2}{ }^{(i)} h_{c}+m_{1}{ }^{(i)} h_{1}{ }^{(i)}\right\}$

摩擦ダンパーを設置する場合は, 総ダンパー耐力 $n_{d} Q_{d}$ を柱通り数 $n_{c}$ で平均化した柱 1 本辺りのダンパー耐力 $\left(n_{d} / n_{c}\right) Q_{d}$ を節点力 $S_{A} m_{2}{ }^{(i)}$ から差し引いて式(74)と式(75)を計算する。ただし, $M_{10}$ は $u_{10}$ が式(76) の時を下限とする。同式は架構全体を等価高さ $0.75 H$ ( $H$ は軒高), 周 期 $0.02 H$ とする 1 自由度系の水平変形であり, ダンパー耐力が過大 で支承が滑らない状態を表す。この方法は最も簡易だが後述のとお りその他の方法よりも過大評価となるため設計法に反映していない。 $u_{\text {all }}=(0.02 H / 2 \pi)^{2}\left(S_{A} / 0.75\right)\left(30 / L^{4}\right)\left(L^{2} y^{2}-2 L y^{3}+y^{4}\right)=2.5 \times 10^{-4} H^{2} S_{A} / \pi^{2}$

\section{2 骨組モデルの静的応力解析を用いた算定手法}

\section{2.1 骨組モデルの構築方法と節点外力の設定方法}

Fig. 6 に RC 片持架構の骨組モデルの概要を示す。骨組モデルで は, アリーナ床レベルの柱脚は固定支持, 境界柱は面外固定, 面内 ピンローラー支持とし, 部材断面 2 次モーメントは曲げ降伏時剛性 低下率 $\alpha_{y}$ を乗じる。節点外力は各種荷重を変換した節点質量に一様 分布の加速度 $S_{A}$ を乗じて算出する。支承部相対変位 $u_{l 0}$ は屋根レベ ル節点のピーク值とし, 柱脚部曲げモーメント $M_{10}$ は解析結果を用 いる。摩擦ダンパーを設置する場合は, 外力から総ダンパー耐力 $n_{d} Q_{d}$ を節点質量 $m_{2}{ }^{(i)}$ で重夕付け平均した相当耐力 $Q_{d}{ }^{(i)}$ を差し引く。ただ し, $M_{l 0}$ は $R_{d} u_{l 0}=u_{\text {all }}($ 式(76))のときを下限值とする。

$$
Q_{d}^{\prime(i)}=n_{d} Q_{d}\left(m_{2}^{(i)} / \sum m_{2}^{(i)}\right)
$$

同手法は部材のせん断変形が無視できない場合にも適用でき, 各 部材の断面検討も同時に行うことができる点が手計算法より優れる。

\section{4. 被災体育館の立体モデルの時刻歴応答解析を用いた妥当性検証 4.1 数值解析概要}

被災体育館の立体モデルの時刻歴応答解析を用いて 3 章の計算手 法の妥当性を比較分析する。Fig. 7 にモデル図と軸組図を, RC 片持 架構の部材諸元は Table 1 に示寸。対象建物は, 2016 年熊本地震に て桁面 RC 片持架構の梁間方向構面外応答が主な被害原因となった A 体育館(Fig.7(a)(c)) と, 2011 年東北地方太平洋沖地震にて妻面 RC 片持架構の桁行方向構面外応答が主な被害原因となった $\mathrm{N}$ 体育館 (Fig.7(b)(d))である。どちらも置屋根体育館であり, A 体育館は 3 階 から上がアリーナ階, $\mathrm{N}$ 体育館は 2 階から上がアリーナ階である。 詳細な建物概要は文献 8) と文献 14)に記す。どちらも筆者らが既往 研究で用いた解析モデルであり, 本章は滑り支承を配置した原設計 モデルと摩擦ダンパー支承を配置した再設計モデルを用意する。特 に RC 部材は割線剛性を適用した 1 次元有限要素でモデル化する。 摩擦ダンパーは耐力 $Q_{d}$, 初期剛性 $100 \mathrm{kN} / \mathrm{mm}, 2$ 次剛性比 0.0001 の 弾塑性 Bilinear 履歴を設定する。Fig. 8 に入力地震動の加速度応答ス ペクトルを示す。入力地震動は 2.1 節式(2)の設計用加速度スペクト

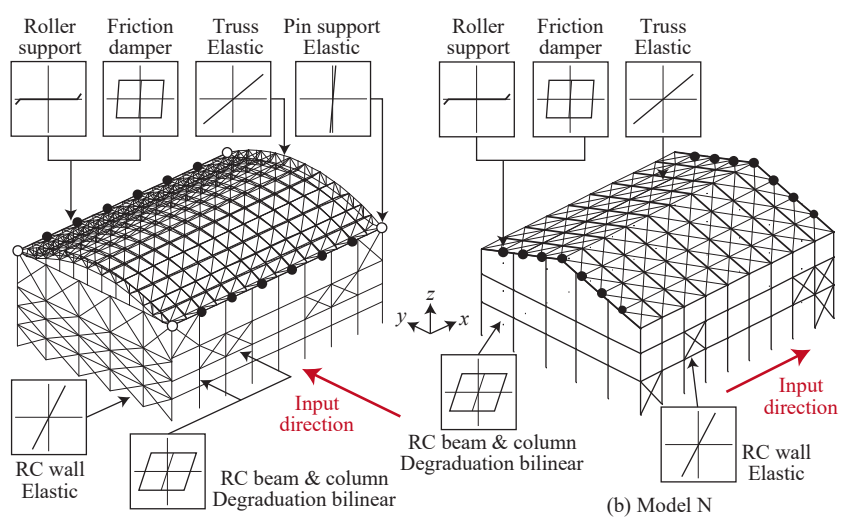

(a) Model A
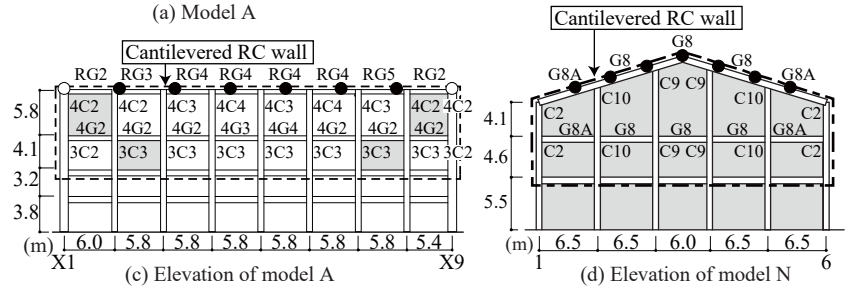

Fig. 7 Schematic image of the actual damaged gymnasia Table 1 Member specifications of cantilevered RC walls

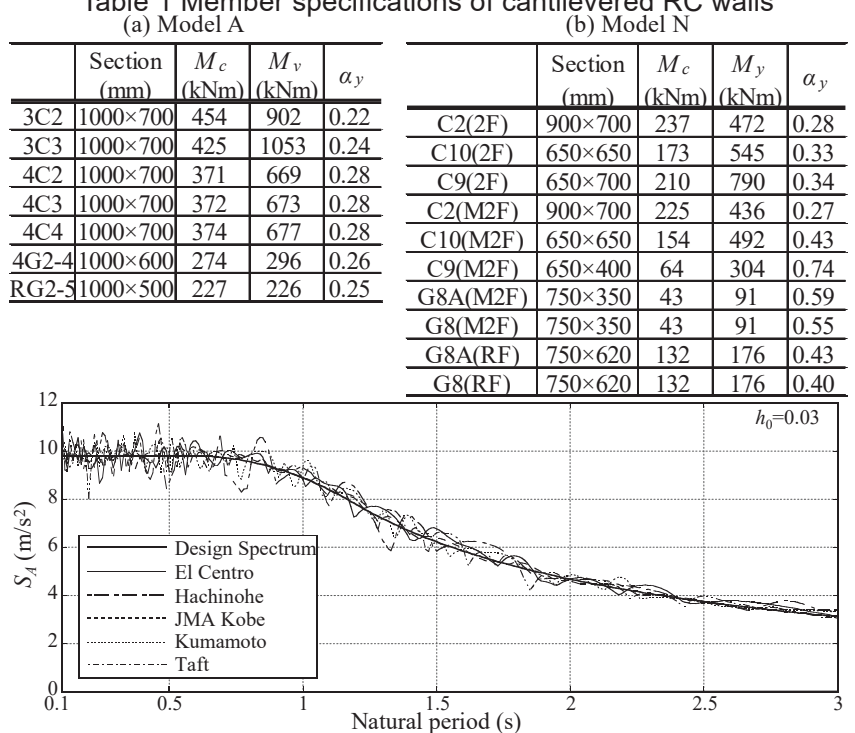

Fig. 8 Acceleration response spectra

ル(減衰比 $3 \%$ )に位相適合した観測 5 波とし, 各体育館の主要な応答 方向(Fig.7)に入力する。時刻歴応答解析(NLRHA)は Newmark $\beta$ 法 $(\beta=1 / 4)$ で解き, 減衰行列は初期の剛性・質量行列に比例するレーリ 一型( 1 次と 2 次の減衰比 $3 \%$ ) とする。なお, 時刻歴応答解析では, $\mathrm{RC}$ 部材の柱脚部が曲げ降伏すると曲げモーメント応答が頭打ちに なるため, 以降は変位応答の評価值と解析結果を比較している。

\section{2 時刻歴応答解析結果の分析と評価值との比較検証}

Fig. 9 に原設計モデルの支承部最大相対変位分布の解析結果を示 す。2.1 節式(2)の設計用加速度スペクトルに位相適合した観測波で も, ピーク最大相対変位 $u_{10}$ は位相により平均值に対して $20 \%$ ばら つく。これが本設計法の式(11)の安全率 1.2 の根拠である。

Fig. 10 に摩擦ダンパー耐力 $Q_{d}$-解析結果関係を示す。同図(a)に 示すように, 支承部ピーク最大相対変位 $u_{l}$ は $Q_{d}$ の上昇に従い零ま で低減する。一方, 同図(b)に示寸ように, RC 片持架構の柱頭絶対 変位は $Q_{d}$ の上昇に対して低減が頭打ちする。これは $Q_{d}$ が上昇する と RC 片持架構が独立して構面外応答寸る状態から, 架構全体と一 
Table 2 Specifications used in the response evaluation of Section 4.

(a) Specification of equivalent beam model or equivalent plate model

\begin{tabular}{|c|c|c|c|c|c|c|c|c|c|c|c|c|c|c|c|c|c|c|c|}
\hline Model & $\begin{array}{c}L \\
(\mathrm{~mm})\end{array}$ & $\begin{array}{c}h_{c} \\
(\mathrm{~mm})\end{array}$ & $\begin{array}{c}h_{g} \\
(\mathrm{~mm})\end{array}$ & \begin{tabular}{|c|}
$E$ \\
$\left(\mathrm{~N} / \mathrm{mm}^{2}\right)$ \\
\end{tabular} & $\begin{array}{c}I_{c e q} \\
\left(\mathrm{~mm}^{4}\right) \\
\end{array}$ & $\begin{array}{c}I_{g e q} \\
\left(\mathrm{~mm}^{4}\right) \\
\end{array}$ & $\begin{array}{c}I_{c}{ }^{\text {center }} \\
\left(\mathrm{mm}^{4}\right)\end{array}$ & $\begin{array}{c}D_{x} \\
(\mathrm{Nmm}) \\
\end{array}$ & $\begin{array}{c}D_{y} \\
(\mathrm{Nmm}) \\
\end{array}$ & $q$ & $q_{p}$ & $\begin{array}{c}\omega_{w} \\
(\mathrm{rad} / \mathrm{s}) \\
\end{array}$ & $\begin{array}{c}\omega_{c} \\
(\mathrm{rad} / \mathrm{s}) \\
\end{array}$ & $\begin{array}{l}T_{w} \\
(\mathrm{~s}) \\
\end{array}$ & $\begin{array}{l}T_{c} \\
(\mathrm{~s}) \\
\end{array}$ & $n_{c}$ & $n_{d}$ & $\begin{array}{l}m_{w} \\
(\mathrm{~kg}) \\
\end{array}$ & $\begin{array}{l}m_{c} \\
(\mathrm{~kg}) \\
\end{array}$ \\
\hline A & 45810 & 9850 & 5750 & \multirow{2}{*}{$\begin{array}{c}21682 \\
F_{c}=21 \\
\left(\mathrm{~N} / \mathrm{mm}^{2}\right)\end{array}$} & $1.668 \mathrm{E}+10$ & $1.121 \mathrm{E}+10$ & $1.674 \mathrm{E}+10$ & $6.315 \mathrm{E}+10$ & $4.225 \mathrm{E}+10$ & 0.409 & 1.576 & 12.19 & 10.16 & 0.52 & 0.62 & 7 & 6 & 331834 & 45465 \\
\hline $\mathrm{N}$ & 32000 & 12600 & 7055 & & $5.962 \mathrm{E}+09$ & $6.484 \mathrm{E}+09$ & $5.784 \mathrm{E}+09$ & $2.020 \mathrm{E}+10$ & $1.993 \mathrm{E}+10$ & 0.617 & 1.682 & 8.24 & 4.95 & 0.76 & 1.27 & 4 & 7 & 176464 & 31577 \\
\hline
\end{tabular}

(b) Member specification of model A

(c) Member specification of model $\mathrm{N}$

\begin{tabular}{|c|c|c|c|c|c|c|c|c|c|c|}
\hline & $\begin{array}{c}\text { Coordinate } \\
x(\mathrm{~mm})\end{array}$ & $\begin{array}{l}h_{1}{ }^{(i)} \\
(\mathrm{mm}) \\
\end{array}$ & $\begin{array}{l}h_{2}{ }^{(i)} \\
(\mathrm{mm})\end{array}$ & $\begin{array}{c}\text { Section } \\
(\mathrm{mm} \times \mathrm{mm})\end{array}$ & $\begin{array}{c}I_{0} \\
\left(\mathrm{~mm}^{4}\right) \\
\end{array}$ & $\alpha_{y}$ & $\phi$ & $\begin{array}{c}I_{1}^{(i)} \\
\left(\mathrm{mm}^{4}\right)\end{array}$ & $\begin{array}{l}I_{2}^{(i)} \\
\left(\mathrm{mm}^{4}\right) \\
\end{array}$ & $\begin{array}{r}I_{\mathrm{g}}^{(j)} \\
\left(\mathrm{mm}^{4}\right)\end{array}$ \\
\hline $3 \mathrm{C} 3$ & 5960 & \multirow{7}{*}{4100} & \multirow{7}{*}{ - } & $\begin{array}{l}1000 \times 700 \\
\end{array}$ & 5.83.E+10 & 0.24 & 1.17 & $1.63 . \mathrm{E}+10$ & \multirow{7}{*}{ - } & \multirow{7}{*}{ - } \\
\hline $3 \mathrm{C} 3$ & 11710 & & & $1000 \times 700$ & $5.83 . \mathrm{E}+10$ & 0.24 & 1.17 & $1.63 . \mathrm{E}+10$ & & \\
\hline $3 \mathrm{C} 3$ & 17460 & & & $1000 \times 700$ & $5.83 . \mathrm{E}+10$ & 0.24 & 1.17 & $1.64 . \mathrm{E}+10$ & & \\
\hline $3 \mathrm{C} 3$ & 23210 & & & $1000 \times 700$ & $5.83 . \mathrm{E}+10$ & 0.24 & 1.17 & $1.64 . \mathrm{E}+10$ & & \\
\hline $3 \mathrm{C} 3$ & 28960 & & & $1000 \times 700$ & $5.83 . \mathrm{E}+10$ & 0.24 & 1.17 & $1.63 . \mathrm{E}+10$ & & \\
\hline $3 \mathrm{C} 3$ & 34710 & & & $1000 \times 700$ & \begin{tabular}{|l|}
$5.83 . \mathrm{E}+10$ \\
\end{tabular} & 0.24 & 1.17 & \begin{tabular}{|l|l}
$1.64 . \mathrm{E}+10$ \\
\end{tabular} & & \\
\hline $3 \mathrm{C} 3$ & 40460 & & & $1000 \times 700$ & \begin{tabular}{|l|}
$5.83 . \mathrm{E}+10$ \\
\end{tabular} & 0.24 & 1.17 & $1.63 . \mathrm{E}+10$ & & \\
\hline $4 \mathrm{C} 2$ & 5960 & \multirow{7}{*}{ - } & \multirow{7}{*}{5750} & $1000 \times 700$ & \begin{tabular}{|l|}
$5.83 . \mathrm{E}+10$ \\
\end{tabular} & 0.28 & 1.11 & \multirow[t]{7}{*}{ 看 } & $1.82 . \mathrm{E}+10$ & \multirow{7}{*}{-} \\
\hline $4 \mathrm{C} 3$ & 11710 & & & $1000 \times 700$ & $5.83 . \mathrm{E}+10$ & 0.28 & 1.11 & & \begin{tabular}{|l|}
$1.83 . \mathrm{E}+10$ \\
\end{tabular} & \\
\hline $4 \mathrm{C4}$ & 17460 & & & $1000 \times 700$ & $5.83 . \mathrm{E}+10$ & 0.28 & 1.11 & & \begin{tabular}{|l|}
$1.83 . \mathrm{E}+10$ \\
\end{tabular} & \\
\hline $4 \mathrm{C} 3$ & 23210 & & & \begin{tabular}{|l|}
$1000 \times 700$ \\
\end{tabular} & $5.83 . \mathrm{E}+10$ & 0.28 & 1.11 & & \begin{tabular}{|l|}
$1.83 . \mathrm{E}+10$ \\
\end{tabular} & \\
\hline $4 \mathrm{C} 4$ & 28960 & & & \begin{tabular}{|l|}
$1000 \times 700$ \\
\end{tabular} & $5.83 . \mathrm{E}+10$ & 0.28 & 1.11 & & \begin{tabular}{|l|}
$1.83 . \mathrm{E}+10$ \\
\end{tabular} & \\
\hline $4 \mathrm{C} 3$ & 34710 & & & $1000 \times 700$ & $5.83 . \mathrm{E}+10$ & 0.28 & 1.11 & & \begin{tabular}{|l|}
$1.83 . \mathrm{E}+10$ \\
\end{tabular} & \\
\hline $4 \mathrm{C} 2$ & 40460 & & & $1000 \times 700$ & \begin{tabular}{|l|}
$5.83 . \mathrm{E}+10$ \\
\end{tabular} & 0.28 & 1.11 & & \begin{tabular}{|l|}
$1.82 . \mathrm{E}+10$ \\
\end{tabular} & \\
\hline RG2 & & \multirow{8}{*}{ - } & \multirow{8}{*}{ - } & $1000 \times 500$ & \begin{tabular}{|l|l|}
$4.17 . \mathrm{E}+10$ \\
\end{tabular} & 0.27 & 1.06 & & & $1.20 . \mathrm{E}+10$ \\
\hline $\mathrm{RG} 3$ & & & & $1000 \times 500$ & \begin{tabular}{|l|l|}
$4.17 . \mathrm{E}+10$ \\
\end{tabular} & 0.25 & 1.06 & & & \begin{tabular}{|l|}
$1.11 . \mathrm{E}+10$ \\
\end{tabular} \\
\hline$\overline{\mathrm{RG} 4}$ & & & & $1000 \times 500$ & $4.17 . \mathrm{E}+10$ & 0.25 & 1.06 & & & \begin{tabular}{|l|}
$1.11 . \mathrm{E}+10$ \\
\end{tabular} \\
\hline$\overline{\mathrm{RG} 4}$ & & & & $1000 \times 500$ & $4.17 . \mathrm{E}+10$ & 0.25 & 1.06 & & & \begin{tabular}{|l|}
$1.11 . \mathrm{E}+10$ \\
\end{tabular} \\
\hline $\mathrm{RG4}$ & & & & $1000 \times 500$ & $4.17 . \mathrm{E}+10$ & 0.25 & 1.06 & & & \begin{tabular}{|l|}
$1.11 . \mathrm{E}+10$ \\
\end{tabular} \\
\hline$\overline{\mathrm{RG} 4}$ & & & & $1000 \times 500$ & $4.17 . \mathrm{E}+10$ & 0.25 & 1.06 & & & \begin{tabular}{|l}
$1.11 . \mathrm{E}+10$ \\
\end{tabular} \\
\hline RG5 & & & & $1000 \times 500$ & $4.17 . \mathrm{E}+10$ & 0.25 & 1.06 & & & \begin{tabular}{|l|}
$1.11 . \mathrm{E}+10$ \\
\end{tabular} \\
\hline $\mathrm{RG} 2$ & & & & \begin{tabular}{|l|}
$1000 \times 500$ \\
\end{tabular} & \begin{tabular}{|l|l}
$4.17 . \mathrm{E}+10$ \\
\end{tabular} & 0.25 & 1.06 & & & \begin{tabular}{|l|}
$1.10 . \mathrm{E}+10$ \\
\end{tabular} \\
\hline
\end{tabular}

体で構面外応答する状態に移行するためである。これが摩擦ダンパ 一による柱脚曲げモーメントの応答低減に下限を設けた根拠である。

Fig. 11 に 3 章の計算手法と解析結果の比較を示す。Table 2 に 3 章 の計算手法に必要な諸元を示す。図中の NLRHA は時刻歴応答解析 結果の平均值, Beam model は棒に基づく評価值(3.1.2 項), Plate model は板に基づく評価值(3.1.3 項), Numerical frame model は骨組モデル の解析值(3.2 項), Simplest static は片持梁のたわみ公式の評価值(3.1.6 項)である。Simplest static は一般によく知られ最も計算が簡単な片持 梁のたわみ公式であるが, Fig.11(a)(b)に示すように, その評価值は 時刻歴応答解析結果(NLRHA)を過剩に過大評価しており, この方法 で応答評価すると不当に不経済な断面検討を招く。これが Simplest static を本設計法に実装しなかった根拠である。 Simplest static と比 べて, 棒または板の評価法(Beam model, Plate model)は NLRHA とよ く対応する。A 体育館の RC 片持架構は, Table 2(a)(b)に示すように, 体育館の長手側かつ $D_{y} / D_{x}$ が小さいため, 棒の評価法(Beam model)で NLRHA を十分に捉えられる。なお, 棒の評価法は, RC 柱の断面が 1 層目と 2 層目で変動しなければ，その RC 柱の断面 2 次モーメント を直接適用して応答評価できるため, Simplest Static と同等に簡便か つ高精度な方法となる。ただし, Table 2(a)(c)に示すように, N 体育 館のような体育館の短手側かつ $D_{y} / D_{x}$ がほぼ 1 に近く等方的な性質 を有する RC 片持架構では, やはり棒の評価法(Beam model)がやや 過大評価となり， RC 梁の剛性を考慮した板の評価法(Plate model)の 方が NLRHA と対応が良くなる。このように RC 片持架構の辺長比 $L / h_{c}$ や RC 柱と $\mathrm{RC}$ 梁の剛性比 $D_{y} / D_{x}$ によって, RC 柱の諸元だけで は RC 片持架構の構面外応答を捉えきれないため, 本設計法の手計 算の計算手法では，棒と板の評価法を両方採用している。一方，骨 組モデルの忘力解析值(Numerical frame model)は RC 片持架構の諸元 によらず，滑り支承のみ $\left(Q_{d}=0 \mathrm{kN}\right)$ の NLRHA を精度良く捉える。本

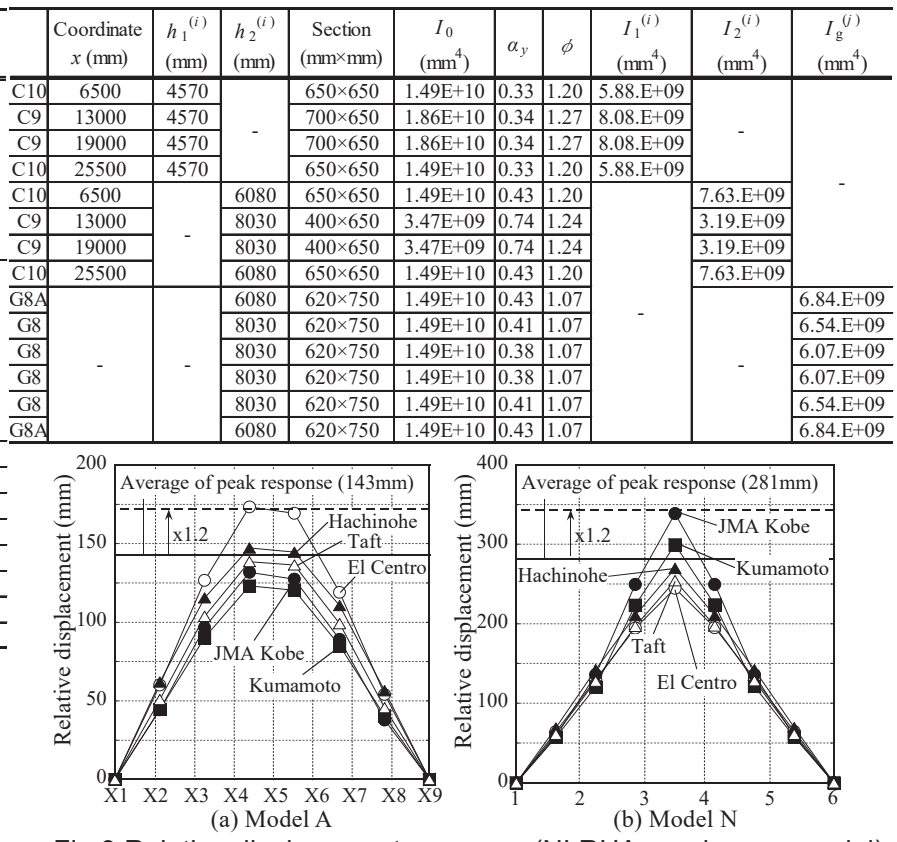

Fig.9 Relative displacement response (NLRHA, no damper model)
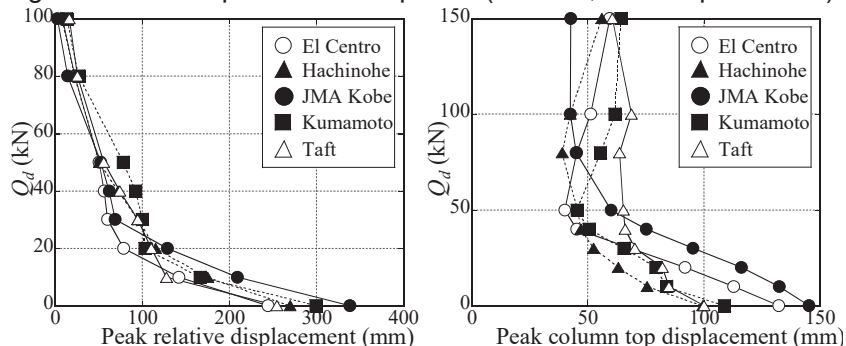

$\begin{array}{ll}\text { (a) Peak relative displacement (Model N) } & \text { (b) Peak column displacement (Model A) }\end{array}$

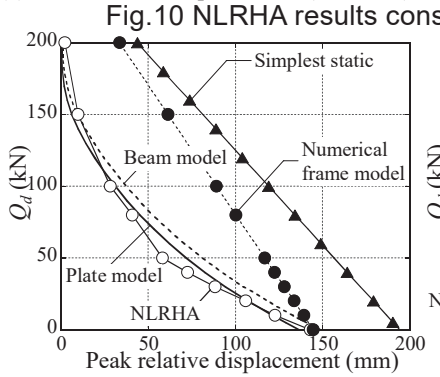
(a) Model A

sidering friction dampers

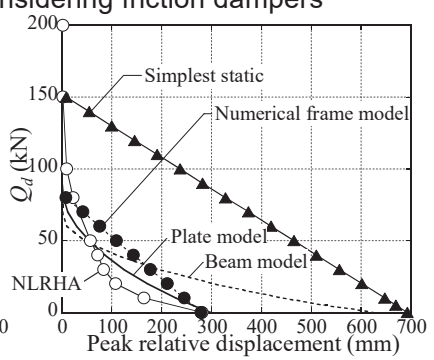

(b) Model N

Fig.11 Comparison of response evaluations and average of NLRHAs

手法は国外の規準で使用される応力算定法(Equivalent lateral force procedure)にも適用できる。ただし, 静的解析では摩擦ダンパーの振 動減衰効果(図中の曲線の様な応答低減効果)は考慮できない。

\section{5. 縮小部分模型の振動台実験結果を用いた妥当性検証}

\section{1 実験概要}

鉄骨置屋根体育館の縮小部分模型の振動台実験結果を用いて 3 章 の計算手法の妥当性を比較分析する。序で述べたように, 同実験は 
$\mathrm{RC}$ 片持架構の挙動把握だけでなく, 屋根卜ラスの座屈崩壊の再現 なども兼裀た多目的な試験となっており，本論文では 3 章の計算手 法の検証に必要な範囲の夕記述する。実験は防災科学技術研究所所 有の大型耐震実験施設にて行っている。

Fig. 12 に試験体立面図を, Photo 1 にセットアップを, Fig. 13 に 屋根支承部側の滑り支承詳細を示す。試験体は A 体育館 ${ }^{14)}$ の $1 / 2.5$ 縮小部分模型であり, アリーナ床レベルより上(3 階と 4 階と R 階) の $\mathrm{RC}$ 片持架構 1 スパンと複層のシステムトラス屋根を抽出し, 慣 性力を模擬するための重鍾(6.21 ton) と屋根支持架台が付属している。 $\mathrm{RC}$ 片持架構の柱は 3 階と 4 階共に幅 $280 \mathrm{~mm} \times$ せい $400 \mathrm{~mm}$ (主筋 12 D13，帯筋・あばら筋 D10@110mm)であり，梁は 4 階が幅 $400 \mathrm{~mm} \times$ せい 600mm (主筋 4-D13, 帯筋・あばら筋 D10@110mm, 腹筋 3-D13), $\mathrm{R}$ 階が幅 $600 \mathrm{~mm} \times$ せい $600 \mathrm{~mm}$ (主筋 5-D13, 帯筋・あばら筋 D10@110mm, 腹筋 3-D13)であり, アンカーボルトを介して振動台 に緊結する基礎梁は幅 $800 \mathrm{~mm} \times$ せい $550 \mathrm{~mm}$ (主筋 8-D22，帯筋・あば ら筋 D10@110mm)である。屋根のシステムトラス部材は外径 $D=34.0 \mathrm{~mm}$, 板厚 $t=2.3 \mathrm{~mm}$ の円形鋼管(STK400)を M12 のボルトで直 径 $85 \mathrm{~mm}$ の中実鋼球ノードと接合した試験体である。部材断面は製 作の都合で原寸の $1 / 2.5$ の近似寸法としている。Fig. 13 に示すよう に，滑り支承は有効ルーズ長さ $\pm 18 \mathrm{~mm}$ であり，4 本の M16 アンカ 一ボルトとダブルナットで R 階梁に緊結されている。摩擦ダンパー は支承側部に取付けて屋根荷重から独立して軸力導入できる仕様 ${ }^{10)}$ としており, 摩擦材は文献 13)と同じである。実験では, 摩擦ダンパ 一の有無, 滑り耐力 $Q_{d}$ に影響するボルト軸力もパラメータとした。 なお, 試験体は境界柱を含まないため, 本章は棒の評価法(3.1.2 項) と片持梁のたわみ公式(3.1.6 項)のみ比較する。

本論文に関係する実験の範囲では, 振動台上の加速度実効值と滑 り支承部の相対変位と反力を計測する。加速度は加速度計で直接計 測する。滑り支承部の相対変位はレーザー変位計で直接計測する。 反力は滑り支承と屋根支持架台のピン支承の間で釣り合うため, 本 実験では, ピン支承に接続するシステムトラス部材の軸力(歪ゲージ 值から計算可能)から滑り支承の反力を換算した。

Fig. 14 に振動台の入力加速度の時刻歴波形と応答スペクトルと減 衰比 $3 \%$ 時の応答スペクトルを示す。入力波は, 2016 年 4 月 16 日の 熊本地震本震の地震波データを基に告示適合波を作成し, 事前の数 值解析を基に実験遂行に必要な応答増幅を検討し,加速度波形を 1.5 倍したものをアリーナ床レベルの応答加速度波形とする。本論文で は，この応答波を振幅倍率 $100 \%$ と定義して振幅を変化させて用い る。各入力の前後には, 試験体の自由振動が停止し, 試験体観察す るための十分な時間を設けている。

\section{2 実験結果と手計算法の比較}

Table 3 に本論に関係する実験結果を示す。同表の減衰比は地震動 入力後にホワイトノイズ加振を行って同定している。同表の滑り荷 重は支承部の荷重変形関係より決定した。手計算手法の評価に用い る加速度応答スペクトル值は振動台上の加速度実効值から計算し, 同表は RC 片持架構の周期と対応する值を掲載している。No.1 4 は 摩擦ダンパー支承の結果であり, No.5 は滑り支承の結果である。た だし, 実際の滑り荷重 $Q_{d}$ は摩擦ダンパーだけでなく支承各部の摩擦 力を含んでおり, 手計算の評価值も $Q_{d}$ を考慮する。具体的な荷重変 形関係の例は付録に示す。同表 $Q_{d}$ は正負の最大值の平均である。

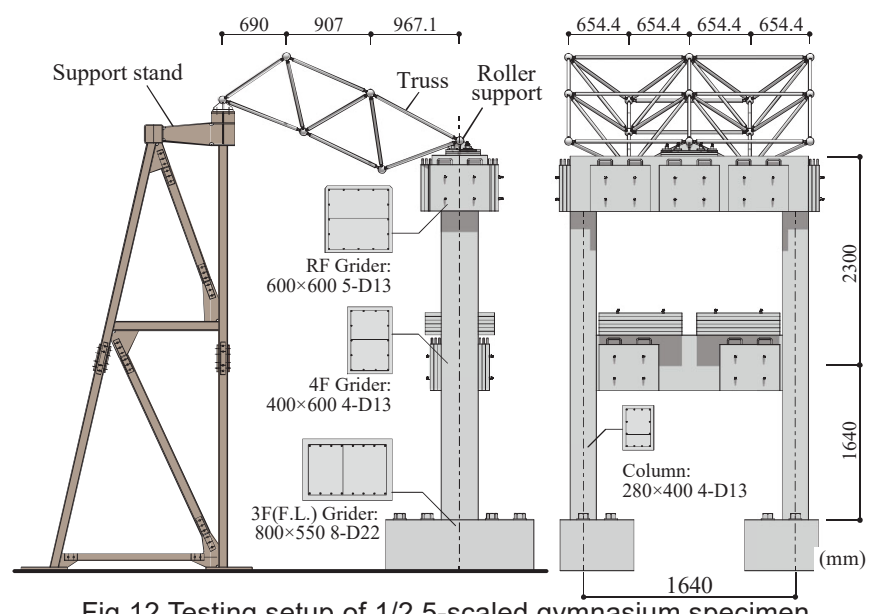

Fig.12 Testing setup of 1/2.5-scaled gymnasium specimen

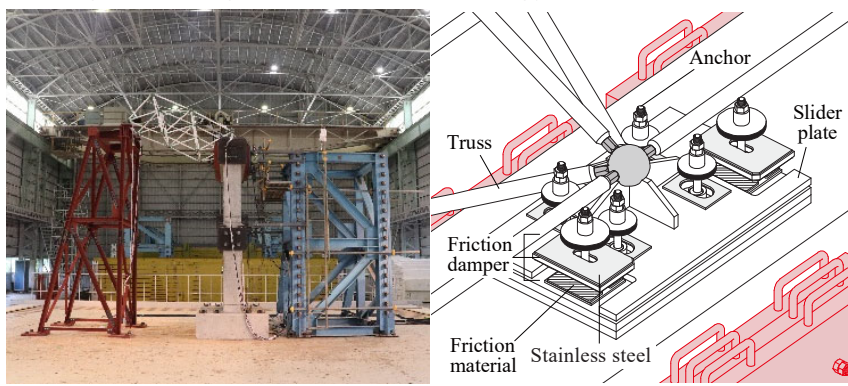

Photo 1 Testing setup Fig.13 Detailed drawings of roof support

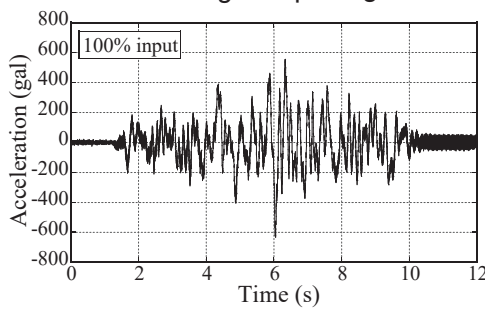

(a) Time history
Fig.14 Input waves

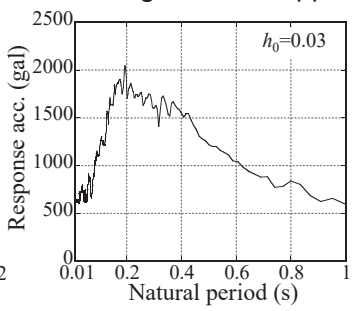

(b) Response spectrum

Table 3 Summary of testing results

\begin{tabular}{c|c|c|c|c}
\hline $\begin{array}{c}\text { Test } \\
\text { No. }\end{array}$ & $\begin{array}{c}\text { Damping ratio } \\
h_{0}(\%)\end{array}$ & $\begin{array}{c}\text { Slip load } \\
Q_{d}(\mathrm{kN})\end{array}$ & $\begin{array}{c}\text { Acc.Spectrum value } \\
S_{A}\left(\mathrm{~m} / \mathrm{s}^{2}\right)\end{array}$ & $\begin{array}{c}\text { Relative displacement } \\
u_{l}(\mathrm{~mm})\end{array}$ \\
\hline $1(100 \%)$ & 2.16 & 32.26 & 16.56 & 13.90 \\
\hline $2(50 \%)$ & 2.88 & 32.88 & 8.77 & 2.70 \\
\hline $3(75 \%)$ & 2.28 & 47.70 & 12.87 & 3.53 \\
\hline $4(50 \%)$ & 2.41 & 8.79 & 9.40 & 10.90 \\
\hline $5(50 \%)$ & 2.98 & 8.97 & 8.68 & 13.97 \\
\hline
\end{tabular}

Table 4 Specifications used in the response evaluation of Section 5 (a) Member specification

\begin{tabular}{c|c|c|c|c|c|c|c|c}
\hline & $\begin{array}{c}h_{1}{ }^{(i)} \\
(\mathrm{mm})\end{array}$ & $\begin{array}{c}h_{2}{ }^{(i)} \\
(\mathrm{mm})\end{array}$ & $\begin{array}{c}\text { Section } \\
(\mathrm{mm})\end{array}$ & $\begin{array}{c}I_{0} \\
\left(\mathrm{~mm}^{4}\right)\end{array}$ & $\alpha_{y}$ & $\phi$ & $\begin{array}{c}I_{1}{ }^{(i)} \\
\left(\mathrm{mm}^{4}\right)\end{array}$ & $\begin{array}{c}I_{2}{ }^{(i)} \\
\left(\mathrm{mm}^{4}\right)\end{array}$ \\
\hline \hline Column (3F) & 1640 & - & $400 \times 280$ & $1.49 \mathrm{E}+09$ & 0.24 & 1.18 & $4.14 \mathrm{E}+08$ & - \\
\hline Column (4F) & - & 2300 & $400 \times 280$ & $1.49 \mathrm{E}+09$ & 0.23 & 1.18 & - & $4.03 \mathrm{E}+08$ \\
\hline
\end{tabular}

(b) Specification of equivalent beam model and simplest static method

\begin{tabular}{c|c|c|c|c}
\hline $\begin{array}{c}E \\
\left(\mathrm{~N} / \mathrm{mm}^{2}\right)\end{array}$ & $\begin{array}{c}I_{c}{ }^{\text {center }} \\
\left(\mathrm{mm}^{4}\right)\end{array}$ & $\begin{array}{c}m_{c} \\
(\mathrm{~kg})\end{array}$ & $\begin{array}{c}m_{1} \\
(\mathrm{~kg})\end{array}$ & $\begin{array}{c}m_{2} \\
(\mathrm{~kg})\end{array}$ \\
\hline 24895 & $4.12 \mathrm{E}+08$ & 6120 & 2678 & 3217 \\
\hline
\end{tabular}

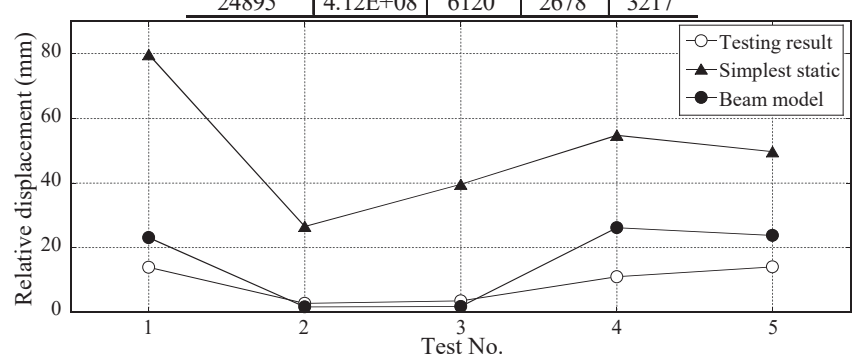

Fig. 15 Comparison of response evaluations and testing results 
Table 4 に手計算手法に必要な計算諸元を, Fig. 15 に支承部最大相 対変位と実験結果の比較を示す。同図に示すように, 棒の評価法 (Beam model)の評価值は, 片持梁のたわみ公式の評価法(Simplest static)の評価值より実験結果(Testing result)との対応が良く, 本実験 の範囲では実験結果に対して $10 \mathrm{~mm} 15 \mathrm{~mm}$ 程度過大評価となり, 本 設計法に適用する応答評価法として妥当であることが確認できた。

\section{6. 結}

本研究は滑り支承で鉄骨造屋根に接続される $\mathrm{RC}$ 片持架構の構面 外応答制御設計法を提案し, 被災体育館の立体モデルの数值解析結 果や縮小部分模型の振動台実験結果を用いて設計法に実装した応答 評価手法の妥当性を比較検証した。本設計法は架構全体の設計に用 いられる現行の地震荷重レベルや実務者の技能レベルを考慮してお り, 特別な知識を必要とせず, 簡易かつ機械的な手続きで RC 片持 架構の構面外応答の検定と具体的な応答制御設計を検討することが できる。本論の検討範囲で得られた結論を以下に示す。

1)RC 片持架構を 1 本の棒に置換した力学モデルは体育館の桁面壁 程度の辺長比 $L / h_{c}(\mathrm{~A}$ 体育館では約 4.5)を有し, $\mathrm{RC}$ 梁と $\mathrm{RC}$ 柱の剛 比 $D_{y} / D_{x}$ が小さい $\mathrm{RC}$ 片持架構の応答評価に適している。 $\mathrm{RC}$ 片持 架構を 1 枚の板に置換した力学モデルは体育館の妻面壁程度の辺 長比 $L / h_{c}(\mathrm{~N}$ 体育館では約 2.5)を有し, $\mathrm{RC}$ 梁の剛性の影響が無視 できない $\mathrm{RC}$ 片持架構の応答評価( $\mathrm{N}$ 体育館では $\left.D_{y} / D_{x} \fallingdotseq 1.0\right)$ に適し ている。棒と板の力学モデルの場合分けの閾值は $q=0.409$ である。 2)RC 片持架構を模擬する骨組モデルの静的応力解析は摩擦ダンパ 一を設置しない場合の支承部ピーク相対変位(被災体育館の時刻 歴応答解析結果)を精度良く捉える。

3)RC 片持架構を 1 本の棒に置換した力学モデルの地震応答評価法 は縮小模型の振動台実験の摩擦ダンパー付き滑り支承部の最大相 対変位を約 10 15mm 程度過大評価するが, 提案設計法に実装する 応答評価法として妥当と考えられる。

4)一般によく知られる片持梁のたわみ公式を利用した静的な評価法

は, 支承部ピーク相対変位を過剩に過大評価し, 不経済な断面検 討を招く可能性がある。

\section{謝辞}

本研究は防災科学技術研究所, 東京工業大学, 工学院大学, 日鉄 エンジニアリングと共同で行った実験結果の一部を引用し，一部に JSPS 基盤研究(B)(No. 18H01676)の助成を戴きました。本設計法の構 築にあたり, 東京大学 山田哲博士，太陽工業 実石明氏，日鉄工 ンジニアリング 松岡祐一博士, 倉田高志氏, 綿貫雄太氏, 建築研 究所 石原直博士, 明治大学 熊谷知彦博士, 東北工業大学 曹氷 博士にご助言を戴きました。また, 本設計法は元東京工業大学 成 田和彦博士, 前原航氏, 稲葉祐介氏, 稲永匠悟氏, 岸澤竜之介氏之 の試行錯誤が結実した成果です。ここに記して皆様に深謝致します。

\section{参考文献}

1) Institute for Sophisticating Technique of Construction in Japan: Concepts for Seismic Diagnosis and Retrofit of Steel Roofs with RC Substructures, Gihodo shuppan, 2015.9 (in Japanese)

日本建設技術高度化機構 : 鉄骨置屋根構造の耐震診断・改修の考え方, 技報堂出版，2015.9

2) MEXT: Criterion for seismic performance of gymnasia, 2006. (in Japanese) 文部科学省：屋内運動場等の耐震性能診断基準，2006.

3) AIJ: Report on the 2016 Kumamoto earthquake, 2018.6 (in Japanese)
日本建築学会 : 2016 年熊本地震被害報告，2018.6

4) Shimada, Y., Yamada, S., Kishiki, S., Hasegawa, T. and Takeuchi, T: Method of reinforcement for joints between steel roofs and RC columns in existing building, Engineering Structures, Vol.209, pp.1-12, 2020.4

5) Ito, K., Yamashita, T. and Watanabe, S.: Cyclic shear loading test and strength evaluation on roof bearings, Journal of Structural and Construction Engineering (Transaction of AIJ), Vol.84, No.759, pp.649-657, 2019.5 (in Japanese)

6) Watanabe, S. and Yamashita, T.: Earthquake response analysis of steel roof gymnasiums considering nonlinear restoring force characteristics of lower structure and roof bearings, Journal of Structural and Construction Engineering (Transaction of AIJ), Vol.85, No.768, pp.209-218, 2020.2 (in Japanese)

7) Narita, K., Takeuchi, T. and Matsui, R: Seismic performance of school gymnasia with steel roofs supported by RC wall frames, Journal of Structural and Construction Engineering (Transaction of AIJ), Vol.78, No.693, pp.1895-1904, 2013.11 (in Japanese)

8) Narita, K., Terazawa, Y., Matsui, R. and Takeuchi, T: Response control of cantilevered RC walls in gymnasia with energy-dissipation roof bearings, Journal of Structural and Construction Engineering (Transaction of AIJ), Vol.80, No.707, pp.157-165, 2015.1 (in Japanese)

9) Narita, K., Takeuchi, T. and Matsui, R.: Seismic response evaluation of cantilevered RC wall frames in school gymnasia with steel roofs, Journal of Structural and Construction Engineering (Transaction of AIJ), Vol.80, No.708, pp.273-283, 2015.2 (in Japanese)

10) Narita, K., Terazawa, T., Maehara, K., Matsuoka, Y., Matsui, R. and Takeuchi, $\mathrm{T}$ : Dynamic loading tests and response evaluation of steel roof bearings with friction dampers, Journal of Structural and Construction Engineering (Transaction of AIJ), Vol.80, No.717, pp.1717-1725, 2015.11 (in Japanese)

11) Narita, K., Takeuchi, T. and Matsui, R.: Seismic response evaluation and design method of steel roof bearing in school gymnasia with cantilevered RC wall frames, AIJ Journal of Technology and Design, Vol.20, No.50, pp.41-46, 2016.2 (in Japanese)

12) Watanuki, Y., Sawaki, S., Kurata, T., Iwamoto, Y., Nishimoto, K and Konishi Y.: Application of energy-dissipation roof bearings with friction dampers Part 1 Overview and design case -, Summaries of Technical Papers of Annual Meeting, Architectural Institute of Japan, Structure 1, pp.883-884, 2018.7 (in Japanese)

綿貫雄太, 澤木俊治, 倉田高志, 岩本雄一, 西本晃治, 小西克尚 : 摩擦 ダンパーによるエネルギー吸収支承の実施例 その 1 エネルギー吸収 支承の概要と設計事例, 日本建築学会大会学術講演梗概集, 構造 I, pp.883-884, 2018.7

13) Inaba, Y., Terazawa, Y., Matsui, R., Kumagai, T. and Takeuchi, T: Response evaluation of cylindrical shell roofs with various bearings supported by RC substructures, Journal of Structural and Construction Engineering (Transaction of AIJ), Vol.83, No.751, pp.1263-1272, 2018.9 (in Japanese)

14) Terazawa, Y., Inanaga, S., Matsui, R. and Takeuchi, T.: Seismic Damage Evaluation of Space Frame Roofs of RC Gymnasiums, Journal of Structural and Construction Engineering (Transaction of AIJ), Vol.83, No.754, pp.1789 $-1799,2018.12$ (in Japanese)

15) Terazawa, Y., Kishizawa, R. and Takeuchi, T.: Comparison of Seismic Damage Design Criteria of Space Frame Roofs Supported by RC Substructures, Steel Construction Engineering, Vol.27, No.107, pp.51-60, 2020.9 (in Japanese)

16) AIJ: AIJ Recommendation for Design of Latticed Shell Roof Structures, 2016.11 (in Japanese) 日本建築学会 : ラチスシェル屋根構造設計指針，2016.11

17) Kato, S.: Approximate stress analysis of framing structures obtained by slab analogies, The state of arts of structural analysis for building structures, Chapter 6, AIJ, 1974.5 (in Japanese)

加藤史郎：連続体置換による骨組の解析，建築構造物の応力解析，第 6 章, 日本建築学会, 1974.5

18) AIJ: AIJ Standard for Allowable Stress Design of Steel Structures, 2019.10 (in Japanese)

日本建築学会 : 鋼構造許容応力度設計規準, 2019.10

19) AIJ: AIJ Standard for Structural Calculation of Reinforce Concrete Structures, 2018.12 (in Japanese)

日本建築学会：鉄筋コンクリート構造計算基準・同解説，2018.12

20) AIJ: Design Recommendations for Composite Constructions, 2010.11 (in 
Japanese)

日本建築学会 : 各種合成構造設計指針・同解説, 2010.11

21) MLIT: Design Manual for Building Structures based on Japanese Building Code, 2020.9 (In Japanese)

国土交通省：2020 版建築物の構造関係技術解説書, 2020.9

22) Terazawa, Y. and Takeuchi, T.: Optimal damper design strategy for braced structures based on generalized response spectrum analysis., Jpn Archit Rev., 2019:00:1-17., $\quad$ https://doi.org/10.1002/2475-8876.12122, accessed 2020.12.08 (参照 2020.12.08)

23) Yamashita, T.: Shell-like buckling and non-linear analysis of shell and spatial structures, Chapter 2, Basic theory and design of shell and spatial structures, Kyoto University Press, 2019.2 (in Japanese)

山下哲郎 : 空間構造の座屈と非線形解析, シェル・空間構造の基礎理論 とデザイン, 第 2 章, 京都大学出版, 2019.2

24) JSSI: Manual for Design and Construction of Passively-Controlled Buildings 3rd Edition, Daioh Co., Ltd, 2013 (in Japanese)

日本免震構造協会 : パッシブ制振構造設計施工マニュアル第 3 版, 2013

\section{付録 1.3 層吹抜けの柱の断面諸元の統合}

3 層吹抜けアリーナの RC 片持架構を 1 本の棒に置換したときの断面 2 次 モーメント $I_{c}^{(i)}$ と断面積 $A_{c}^{(i)}$ は, 2 層吹抜けの場合と同様に式(A1)の補歪エネ ルギーを等置すると式(A2)と式(A3)で評価できる。

$$
\begin{aligned}
& W_{d}=\frac{1}{2} \int_{0}^{h_{3}^{(i)}} \frac{(P x)^{2}}{E I_{3}^{(i)}} d x+\frac{1}{2} \int_{h_{3}^{(i)}}^{\left(h^{(i)}+h_{3}^{(i)}\right)} \frac{(P x)^{2}}{E I_{2}^{(i)}} d x+\frac{1}{2} \int_{\left.h_{2}^{(i)}+h_{3}^{(i)}\right)}^{h^{(i)}} \frac{(P x)^{2}}{E I_{1}^{(i)}} d x, \quad W_{d}=\frac{1}{2} \int_{0}^{h^{(i)}} \frac{(P x)^{2}}{E I_{c}^{(i)}} d x \\
& I_{c}^{(i)}=\frac{I_{1}^{(i)} I_{2}^{(i)} I_{3}^{(i)}\left(h^{(i)}\right)^{3}}{\left(I_{1}^{(i)} I_{2}^{(i)}-I_{1}^{(i)} I_{3}^{(i)}\right)\left(h_{3}^{(i)}\right)^{3}+\left(I_{2}^{(i)} I_{3}^{(i)}-I_{1}^{(i)} I_{3}^{(i)}\right)\left(h_{2}^{(i)}+h_{3}^{(i)}\right)^{3}+I_{1}^{(i)} I_{2}^{(i)}\left(h^{(i)}\right)^{3}} \\
& A_{c}^{(i)}=\frac{A_{1}^{(i)} A_{2}^{(i)} A_{3}^{(i)} h^{(i)}}{A_{1}^{(i)} h_{2}^{(i)} h_{3}^{(i)}+A_{2}^{(i)} h_{1}^{(i)} h_{3}^{(i)}+A_{3}^{(i)} h_{1}^{(i)} h_{2}^{(i)}}
\end{aligned}
$$

ここに $I_{3}^{(i)}$ と $A_{3}^{(i)}$ はアリーナ床レベルから見て 3 層目の柱の断面 2 次モーメン トと断面積, $h_{3}{ }^{(i)}$ は 3 層目の階高である。

付録 2. 係数 $r$ について

第 2 章の式(12)の係数 $r$ は, 中央 $(y=0.5 L)$ で 1.0 に無次元化した一様分布荷 重を受ける両端固定梁のたわみ変形分布であり，式(A4)で精算可能である。

$r=16\left\{(y / L)^{2}-2(y / L)^{3}+(y / L)^{4}\right\}$

\section{付録 3. 各境界条件に対応した $n$ 次の形状関数と無次元化振動数 $\lambda$}

各境界条件に対応した $n$ 次の形状関数は式(A5), 式(A7), 式(A9)で表され る。対応する無次元化振動数 $\lambda$ は超越方程式(式(A6), 式(A8), 式(A10))の解で ある。ここで $\xi$ は無次元化座標 $(0.0 \leqq \xi \leqq 1.0)$ である。

(a) 固定端-自由端

$w(\xi)=+(\cos \lambda+\cosh \lambda)(\sin \lambda \xi-\sinh \lambda \xi)-(\sin \lambda+\sinh \lambda)(\cos \lambda \xi-\cosh \lambda \xi)$

$1+\cos \lambda \cosh \lambda=0 \quad \therefore \lambda_{1}=1.875, \lambda_{2}=4.694$

(b) 固定端-ピン端

$w(\xi)=-(\cos \lambda+\cosh \lambda)(\cos \lambda \xi-\cosh \lambda \xi)+(\sin \lambda+\sinh \lambda)(\sin \lambda \xi-\sinh \lambda \xi)$

$\sin \lambda \cosh \lambda=\cos \lambda \sinh \lambda \quad \therefore \lambda_{1}=3.927, \lambda_{2}=7.069$

(c) 固定端-固定端

$w(\zeta)=+(\cos \lambda-\cosh \lambda)(\cos \lambda \xi-\cosh \lambda \xi)+(\sin \lambda+\sinh \lambda)(\sin \lambda \xi-\sinh \lambda \xi)$

$1-\cos \lambda \cosh \lambda=0 \quad \therefore \lambda_{1}=4.730, \lambda_{2}=7.853$

付録 4. 板のポテンシャルエネルギー $V$ と運動エネルギー $T$

板厚 $t_{e q}$, 密度 $\rho$ の板のポテンシャルエネルギーVは式(A11)で, 運動エネル ギーTは式(A12)で計算可能である。

$$
\begin{aligned}
& V=\frac{1}{2} \iint\left[D_{x} \frac{\partial^{4} w}{\partial x^{4}}+2\left(D_{1}+2 D_{x y}\right) \frac{\partial^{4} w}{\partial x^{2} \partial y^{2}}+D_{y} \frac{\partial^{4} w}{\partial y^{4}}\right] d x d y \\
& T=\frac{1}{2} \rho t_{e q} \iint\left(\frac{\partial \zeta}{\partial t}\right)^{2} d x d y=\frac{\omega^{2} \rho t_{e q}}{2} \iint(w(x, y))^{2} d x d y
\end{aligned}
$$

付録 5. 摩擦ダンパー導入時の柱設計用せん断力 $Q_{s d}$

摩擦ダンパーによる応答低減効果を考慮した場合の柱のせん断力は, 支承 が滑らず摩擦ダンパーが機能しない場合の式(A13)を下限とする式(15)と式 (A14)で計算できる。式(A13)に示すように, 摩擦ダンパーの導入により柱設計 用せん断力は最大約 10 30\%低減できる。

$$
\begin{aligned}
Q_{s p} & = \begin{cases}13.679 Q_{s}\left(q / q_{p}\right)^{2} & (q>0.409) \\
0.7109 Q_{s} & (q \leq 0.409)\end{cases} \\
Q_{s d} & =\text { Maximum of }\left\{R_{d} Q_{s}, Q_{s p}\right\}
\end{aligned}
$$

付録 6 ，地上加速度に対するアリーナ床上の応答加速度

Table A1 に地上加速度(G.L.) に対するアリーナ床上の応答加速度の最大值 の比較を示寸。同表は 4 章の原設計モデルの数值解析結果である。地震波に よるバラツキはあるものの, アリーナ床上の応答加速度は殆ど地動入力と同 等であることが分かっており, 本設計法の地震荷重では, 地動入力の加速度 応答スペクトルで RC 片持架構の応力と変形を算出する仕様としている。な お, 学校体育館では, アリーナの下層は特別教室や武道場が配置される壁付 $\mathrm{RC}$ ラーメン構造が採用されていることが少なくない。

Table A1 Comparison of the maximum floor accelerations

\begin{tabular}{c|c|c|c|c|c|c}
\hline & \multicolumn{7}{|c}{ Maximum acceleration $\left(\mathrm{m} / \mathrm{s}^{2}\right)$} \\
\cline { 2 - 8 } & El Centro & Hachinohe & JMA Kobe & Kumamoto & Taft & Average \\
\hline \hline G.L. & 5.37 & 5.52 & 4.94 & 7.06 & 6.08 & 5.80 \\
\hline A(3FL) & 5.99 & 5.33 & 6.08 & 5.84 & 6.08 & 5.87 \\
\hline N(2FL) & 5.48 & 6.39 & 5.43 & 5.79 & 5.71 & 5.76 \\
\hline \hline A/G.L. & 1.12 & 0.97 & 1.23 & 0.83 & 1.00 & 1.03 \\
\hline N/G.L. & 1.02 & 1.16 & 1.10 & 0.82 & 0.94 & 1.01 \\
\hline
\end{tabular}

付録 7. 摩擦ダンパー導入による柱脚部曲げモーメントM の低減効果の例

Fig.A1 に 4 章の被災体育館に摩擦ダンパーを導入した場合の RC 片持架構 の柱脚部曲げモーメントの各種評価值を比較している。なお, 本設計法に従 うと A 体育館は Beam model, N 体育館は Plate model で評価することになる。

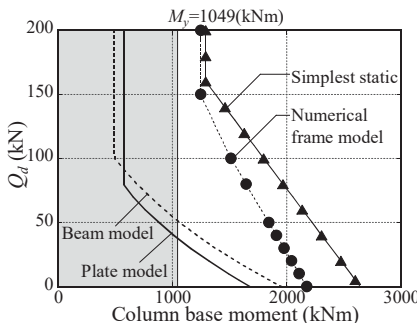

(a) Model A (Beam model is actually used.)

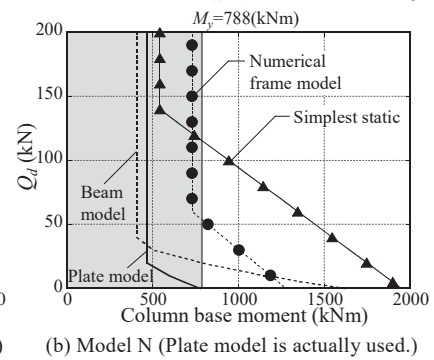

(b) Model N (Plate model is actually used.) ues of column base moment

\section{付録 8. 振動台実験結果の例}
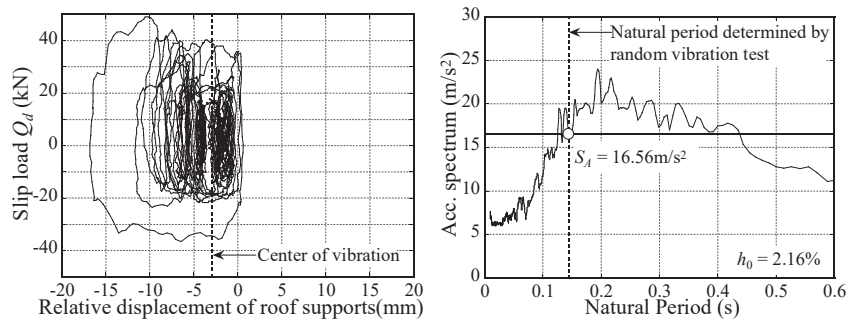

(a) Load-deformation relationship of roof suppor

Fig.A2 Example result of the shaking table test (No.1)

付録 9. 支承部アンカーボルトの衝突反カ

Fig. A3 に支承部アンカーボルトがルーズホール端部に接触する時の衝突反 力時刻歷の例を示す。同図は 5 章の振動台実験の計測方法確認の予備実験結 果(正弦波加振)である。予備実験は角型鋼管の片持鉄骨柱を用いて行い, 歪ゲ ージ值から換算される曲げ歪と頂部集中荷重をうける片持梁のモーメント分 布から柱のベースシア $Q$ と柱脚曲げモーメント $M$ を算出した。同図に示すよ うに, 5.55 秒付近でアンカーボルトがルーズホール端部に接触し, 支承部 に $8 \mathrm{kN}$ の衝突反力が発生した。仮に衝突反力 $8 \mathrm{kN}$ が柱を押し返寸力として有 効であるとすれば，柱高さより柱脚曲げモーメントは静的な釣合では 約 $31.5 \mathrm{kNm}$ の低減が見込める。しかし, 同図に示寸ように, 実際は反力の発 生時間は短く動的には $9 \mathrm{kNm}$ 程度の低減しか確認できなかった。低減量を正 確に評価する実験データも少なく, 本設計法の強度型設計(Design option 2)の 設計用せん断力 $Q_{s}($ 式(15)) では, 衝突力の低減を見込まない仕様としている。
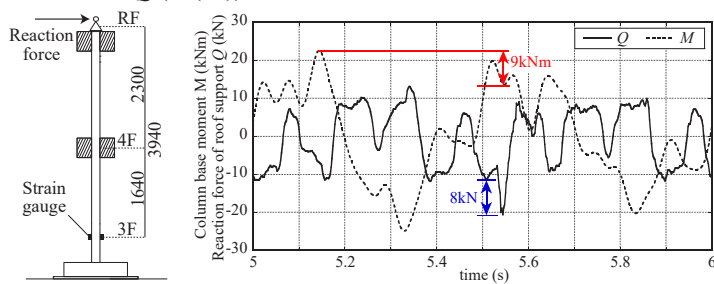

Fig. A3 Reduction of bending moment by collision reaction force 


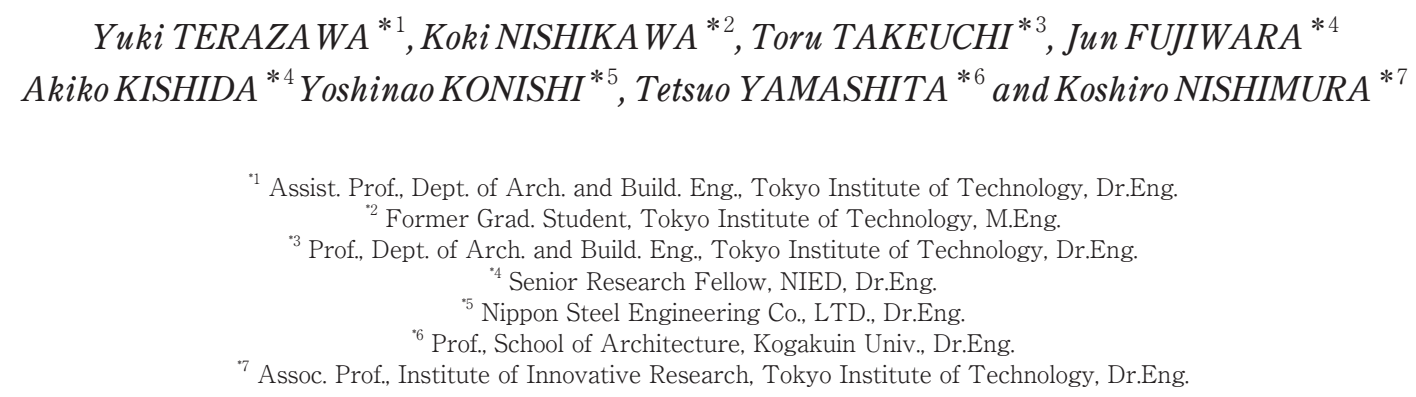

In steel roof gymnasiums with RC substructures, out-of-plane response of cantilevered RC walls are predominant during seismic responses, which triggers sequential damages of structural or non-structural components. Detailed regulations have been not included in the current Japanese building code yet even though Gymnasium is used as a shelter in disaster. In this paper, a design procedure for out-of-plane response control of a cantilevered RC wall connected by roller supports to metal spatial roof was proposed. While many researchers proposed response evaluation methods for cantilevered RC walls, those methods are too complicated to be implemented in the actual design process. Therefore, the proposed design procedure is carefully formulated based on Japanese structural engineer's practice. The design equation is derived from both equivalent linear approach simulating damping effect and continuum mechanics where a cantilevered RC wall is modeled as single beam or single plate. In Section 2, the detailed design procedure (the scope, the design criteria, the seismic load and the actual design process) is carefully explained for engineers. In Section 3, the derivation process from the response evaluation to the design equations is explained. Both single beam and single plate are modeled as secant bending stiffness of RC members yielding. In Section 4, the response evaluation values are compared with the numerical simulation results of the actual damage gymnasia. In Section 5, the response evaluation values are compared with a shake table testing of $1 / 2.5$-scaled model of school gymnasium. In summary, the following results were obtained:

1) Both of single beam model and single plate model are more accurate than simplest formulas of cantilevered beam against non-linear response history analysis results of the actual damaged gymnasia. The single beam model is suitable for a cantilevered RC wall where span is long and the bending stiffness of beam is negligible. The single plate model is suitable for a cantilevered RC wall where span is short and the bending stiffness of beam is not negligible. Threshold value is 0.409 of the coefficient $q$ determined by both width-to-height ratio $L / h_{c}$ and bending stiffness ratio $D_{y} / D_{x}$.

2) The static stress analysis results of numerical frame model composed of only the cantilevered RC wall was corresponding to the non-linear response history analysis results of the damaged gymnasia with no friction dampers.

3) The response evaluation results of the single beam model was corresponding with error $10 \mathrm{~mm}$ to $15 \mathrm{~mm}$ to the shake table testing results.

4) The response evaluation results of the simplest static formula of a cantilevered beam were too conservative compared with the others, and may produce uneconomical design. 